\title{
Cattle manure compost and biochar supplementation improve growth of Onobrychis viciifolia in coal-mined spoils under water stress conditions
}

\author{
Rana Roy ${ }^{\mathrm{a}, \mathrm{b}}$, Avelino Núñez-Delgado ${ }^{\text {, }}$, Jinxin Wang ${ }^{\mathrm{a}, \mathrm{d}, *}$, Md Abdul Kader ${ }^{\mathrm{e}, \mathrm{f}, \mathrm{g}}$, Tanwne Sarker ${ }^{\mathrm{h}}$, \\ Ahmed Khairul Hasan ${ }^{i}$, Turgay Dindaroglu ${ }^{j}$ \\ ${ }^{a}$ College of Natural Resources and Environment, Northwest A\&F University, Yangling, Shaanxi, 712100, People's Republic of China \\ ${ }^{\mathrm{b}}$ Department of Agroforestry \& Environmental Science, Sylhet Agricultural University, Sylhet, 3100, Bangladesh \\ ${ }^{\mathrm{c}}$ Department of Soil Science and Agricultural Chemistry, Engineering Polytechnic School, Campus Univ., 27002, Lugo, University of Santiago de Compostela, Spain \\ ${ }^{\mathrm{d}}$ Key Laboratory of Plant Nutrition and the Agri-Environment in Northwest China, Ministry of Agriculture, Yangling, Shaanxi, 712100, People's Republic of China \\ ${ }^{\mathrm{e}}$ School of Agriculture, Geography, Environment, Ocean and Natural Sciences, University of the South Pacific, Suva, 1168, Fiji \\ ${ }^{\mathrm{f}}$ Department of Soil Science, Bangladesh Agricultural University, Mymensingh, 2202, Bangladesh \\ ${ }^{g}$ College of Science, Health, Education and Engineering, Murdoch University, Murdoch, WA, 6150, Australia \\ ${ }^{\mathrm{h}}$ School of Economics and Finance, Xi'an Jiaotong University, Xi'an, 710049, People's Republic of China \\ ${ }^{i}$ Department of Agronomy, Bangladesh Agricultural University, Mymensingh, 2202, Bangladesh \\ ${ }^{j}$ Department of Forest Engineering, Faculty of Forestry, Kahramanmaras Sutcu Imam University, Kahramanmaras, 46100, Turkey
}

\section{A R T I C L E I N F O}

\section{Keywords:}

Onobrychis viciifolia

Compost

Revegetation

Water-shortage

Wood biochar

\begin{abstract}
A B S T R A T
Surface mining is a critical anthropogenic activity that significantly alters the ecosystem, while the use of appropriate revegetation techniques can be considered an important and feasible strategy in the way to improve the ecosystem services of degraded land. In the present study, we carried out a pot experiment to investigate the effects of three different variables on morpho-physiological and biochemical parameters of Onobrychis viciifolia to assess the capability of this species to be used for restoration purposes. Specifically, the variables studied were: (a) water (W) regime, working at five values as regards field capacity (FC) (i.e., $80 \% \mathrm{FC}=$ highest, $72 \% \mathrm{FC}=$ high, $60 \% \mathrm{FC}=$ moderate, $48 \% \mathrm{FC}=$ low, and $40 \% \mathrm{FC}=$ very-low dose); and (b) rates of cattle manure compost (CMC) and wood biochar (BC) (weight/weight ratio), working at five rates (i.e., $4.0 \%=$ highest, $3.2 \%=$ high, $2.0 \%=$ moderate, $0.8 \%=$ low, and $0 \%=$ either no-CMC or no-BC dose). In addition, soil physical-chemical properties and enzyme activities were also investigated at the end of the experimental period. It was found that morphological growth attributes such as plant height, maximum root length, and dry biomass significantly increased with W, CMC and BC applications. Compared to control, moderate-to-high W, CMC and BC doses $\left(\mathrm{W}_{80} \mathrm{CMC}_{2} \mathrm{BC}_{2}\right)$ increased net photosynthesis rate (by $42 \%$ ), stomatal conductance (by $50 \%$ ), transpiration rate (by 29\%), water use efficiency (by 10\%), chlorophyll contents (by 73\%), carotenoid content (by $81 \%$ ), leaf relative water content (by 33\%) and leaf membrane stability index (by 30\%). Under low-W content, the application of CMC and BC enhanced osmotic adjustments by increasing the content of soluble sugar and the activities of superoxide dismutase, catalase, peroxidase and ascorbate peroxidase, decreasing the oxidative stress, as verified by low levels of hydrogen peroxide, superoxide anion, malondialdehyde and proline contents in leaf tissues. Moreover, application of W, CMC and BC significantly improved soil water holding capacity, available nitrogen, phosphorus and potassium, urease and catalase activities, which facilitate plant growth. These results would aid in designing an appropriate strategy for achieving a successful revegetation of $O$. viciifolia, providing optimum doses of W (64\% field capacity), CMC (2.4\%) and BC (1.7\%), with the final aim of reaching ecological restoration in arid degraded lands.
\end{abstract}

\footnotetext{
* Corresponding author. College of Natural Resources and Environment, Northwest A\&F University, Yangling, Shaanxi, 712100, People’s Republic of China.

E-mail addresses: ranaroy.aes@sau.ac.bd (R. Roy), avelino.nunez@usc.es (A. Núñez-Delgado), jxwang2002@126.com, jwang118@nwsuaf.edu.cn (J. Wang), mdabdul.kader@usp.ac.fj (M.A. Kader), tanwnesarker@gmail.com (T. Sarker), akhasan@bau.edu.bd (A.K. Hasan), turgaydindaroglu@ksu.edu.tr (T. Dindaroglu).
} 
Table 1

Experimental design and arrangement of treatments.

\begin{tabular}{|c|c|c|c|c|c|c|c|}
\hline \multirow[t]{2}{*}{ Treatments no. } & \multirow[t]{2}{*}{ Treatments details } & \multicolumn{3}{|c|}{ Coded values } & \multicolumn{3}{|c|}{ Quantity applied } \\
\hline & & Water (W) & Cattle manure compost (CMC) & Wood biochar (BC) & $\mathrm{W}(\% \mathrm{FC})$ & CMC (\% w/w) & $\mathrm{BC}(\% \mathrm{w} / \mathrm{w})$ \\
\hline 1 & $\mathrm{~W}_{72} \mathrm{CMC}_{3.2} \mathrm{BC}_{3.2}$ & 1 & 1 & 1 & 72 & 3.2 & 3.2 \\
\hline 2 & $\mathrm{~W}_{72} \mathrm{CMC}_{3.2} \mathrm{BC}_{0.8}$ & 1 & 1 & -1 & 72 & 3.2 & 0.8 \\
\hline 3 & $\mathrm{~W}_{72} \mathrm{CMC}_{0.8} \mathrm{BC}_{3.2}$ & 1 & -1 & 1 & 72 & 0.8 & 3.2 \\
\hline 4 & $\mathrm{~W}_{72} \mathrm{CMC}_{0.8} \mathrm{BC}_{0.8}$ & 1 & -1 & -1 & 72 & 0.8 & 0.8 \\
\hline 5 & $\mathrm{~W}_{48} \mathrm{CMC}_{3.2} \mathrm{BC}_{3.2}$ & -1 & 1 & 1 & 48 & 3.2 & 3.2 \\
\hline 6 & $\mathrm{~W}_{48} \mathrm{CMC}_{3.2} \mathrm{BC}_{0.8}$ & -1 & 1 & -1 & 48 & 3.2 & 0.8 \\
\hline 7 & $\mathrm{~W}_{48} \mathrm{CMC}_{0.8} \mathrm{BC}_{3.2}$ & -1 & -1 & 1 & 48 & 0.8 & 3.2 \\
\hline 8 & $\mathrm{~W}_{48} \mathrm{CMC}_{0.8} \mathrm{BC}_{0.8}$ & -1 & -1 & -1 & 48 & 0.8 & 0.8 \\
\hline 9 & $\mathrm{~W}_{80} \mathrm{CMC}_{2} \mathrm{BC}_{2}$ & 1.682 & 0 & 0 & 80 & 2 & 2 \\
\hline 10 & $\mathrm{~W}_{40} \mathrm{CMC}_{2} \mathrm{BC}_{2}$ & -1.682 & 0 & 0 & 40 & 2 & 2 \\
\hline 11 & $\mathrm{~W}_{60} \mathrm{CMC}_{4} \mathrm{BC}_{2}$ & 0 & 1.682 & 0 & 60 & 4 & 2 \\
\hline 12 & $\mathrm{~W}_{60} \mathrm{CMC}_{0} \mathrm{BC}_{2}$ & 0 & -1.682 & 0 & 60 & 0 & 2 \\
\hline 13 & $\mathrm{~W}_{60} \mathrm{CMC}_{2} \mathrm{BC}_{4}$ & 0 & 0 & 1.682 & 60 & 2 & 4 \\
\hline 14 & $\mathrm{~W}_{60} \mathrm{CMC}_{2} \mathrm{BC}_{0}$ & 0 & 0 & -1.682 & 60 & 2 & 0 \\
\hline 15 & $\mathrm{~W}_{60} \mathrm{CMC}_{2} \mathrm{BC}_{2}$ & 0 & 0 & 0 & 60 & 2 & 2 \\
\hline 16 & $\mathrm{~W}_{60} \mathrm{CMC}_{2} \mathrm{BC}_{2}$ & 0 & 0 & 0 & 60 & 2 & 2 \\
\hline 17 & $\mathrm{~W}_{40} \mathrm{CMC}_{0} \mathrm{BC}_{0}, \mathrm{CK}$ & -1.682 & -1.682 & -1.682 & 40 & 0 & 0 \\
\hline
\end{tabular}

\section{Introduction}

Coal mine spoils are a form of solid waste that is generated during the coal mining process (Sun et al., 2009). Long-term spoils storage can result in resource depletion and land waste, posing serious risks to the environment and human health (Wong, 2003). For the maintenance of "green mines", ecological restoration of coal mine waste is of great importance. Revegetation is a prerequisite for ecological restoration because it enables ecological functions (Xu et al., 2020), and has gained popularity due to its economic and environmental benefits. Revegetation has the potential to improve soil quality and support human habitation in degraded regions (Li et al., 2017; Yu et al., 2020). However, in areas with acute water shortages like Northwest China, revegetation depends profoundly on artificial irrigation, since groundwater is usually inaccessible in that region (Gao et al., 2016). In practice, covering soil, and/or inorganic and organic amendments are normally applied to support the revegetation in such degraded land (Roy et al., 2022, 2021 b, 2021d; Xie and van Zyl, 2020).

Utilization of cattle manure compost (CMC) increases humic substances, such as organic matter, humus, humate, humic acid, fulvic acid and humin which play a vital role in soil fertility and plant nutrition (Zinati et al., 2001). Plants grown on soils that contain adequate humin, humic acids, and fulvic acids are less subject to stress (Adil Aydin, 2012). A recent study by Wang et al. (2018) shows that the insufficient utilization of CMC poses environmental and human health risks in China. Taking these social problems into consideration, as well as potential cost-efficient measures, the use of CMC as a soil amendment to support a revegetation program could be considered very interesting.

In addition to CMC, the application of wood biochar (BC) can be a practical solution to enhance plant growth under conditions of water shortage. Biochar results from bio-residues that are thermochemically degraded in an absent or limited oxygen environment, generating a porous material with a high carbon density. Biochar application has a positive impact on soil pores, aggregate structure, water and nutrient retention capacity (Beesley et al., 2011; Bianco et al., 2021). The presence of plant nutrients and higher content of recalcitrant organic carbon in the biochar and its suitability for microbial habitat due to its porous structure are considered as the main reasons for the improvement in soil properties and increase in plan nutrient uptake in biochar amended soils (Bianco et al., 2021; Nigussie et al., 2012; Rahman et al., 2021). Cybulak et al. (2016) reported that the application of biochar increases the hygroscopic moisture content of soil (by 1.5-3.0\%), which would be very beneficial to dry and degraded soils. It was reported that pyrolysis condition and feedstock type significantly affected the structural and physicochemical characteristics of the resulting biochar products
(Claoston et al., 2014). Previous results indicated that higher temperatures (above $500^{\circ} \mathrm{C}$ ) resulted in a higher $\mathrm{C}$ content, while the losses of $\mathrm{N}$, hydrogen $(\mathrm{H})$ and oxygen $(\mathrm{O})$ were also recorded (Liang et al., 2016). However, low-temperature biochars (obtained at $250-400{ }^{\circ} \mathrm{C}$ ) were found to be more suitable for improving soil fertility due to their relatively less stable aromatic backbone from pyrolysis and more $\mathrm{C}=\mathrm{O}$ and $\mathrm{C}-\mathrm{H}$ functional groups that may serve as nutrient exchange sites after oxidation (Tag et al., 2016). Yuan et al. (2011) showed that a mix of rice husk and cotton seed biochar produced through pyrolysis at $400{ }^{\circ} \mathrm{C}$ enhanced soil water holding capacity under reduced irrigation and improved plant growth, making it comparable to that under full irrigation. Likewise, Pradhan et al. (2020) found that the optimum temperature for pyrolysis was around $400^{\circ} \mathrm{C}$. Moreover, the selection of suitable plant species is also very important to accelerate any revegetation program. Onobrychis viciifolia is a plant species well known for its drought tolerance, because of its well-developed root system with many root nodules and good fertilization capability (Niu and Li, 2003). As a leguminous species, $O$. viciifolia has demonstrated a series of physiological and biochemical mechanisms to adapt to water stress conditions and live-in nutrient-deficient coal mine wastes (Kong et al., 2014).

There is substantial evidence that compost and biochar can increase soil fertility status and a plant's resistance to stress in degraded environments (Antonious, 2018; Pandey et al., 2021; Ren et al., 2021; Roy et al., 2021b). However, less is known about the impact of the coupling effect of water (W), CMC and BC on the morphological, physiological and biochemical growth responses of $O$. viciifolia planted on coal-mined spoil. In this context, the main objectives of the present study are the following: (i) to address the morphological, physiological and biochemical growth response of $O$. viciifolia, as well as soil physical-chemical properties and enzyme activities under various regimes of W, CMC and BC doses in a coal mine soil; (2) to identify the optimum W-CMC-BC application dose. These findings could have important environmental implications, specifically in relation to the recycling of waste materials and promotion of revegetation and the subsequent restoration of degraded areas.

\section{Materials and methods}

A pot trail was performed in a greenhouse at the Northwest Agriculture and Forestry University $\left(34^{\circ} 15^{\prime} 60^{\prime \prime} \mathrm{N}, 108^{\circ} 3^{\prime} 46^{\prime \prime} \mathrm{E}\right)$, China. Coalmined spoil was collected from Lingwu, China, and sampled according to our previous study, Roy et al. (2020b). The CMC and BC (the latter made by pyrolyzing apple wood at $400{ }^{\circ} \mathrm{C}$ ) were obtained from Yangling, China. BC was obtained by slow pyrolysis of apple wood at approximately $400{ }^{\circ} \mathrm{C}$ in a biochar kiln operating under low oxygen 
Table 2

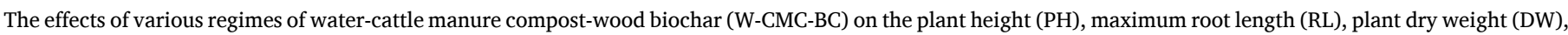

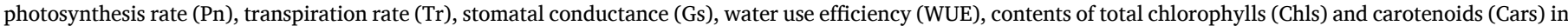

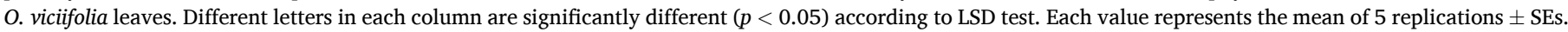

\begin{tabular}{|c|c|c|c|c|c|c|c|c|c|}
\hline Treatments & $\mathrm{PH}(\mathrm{cm})$ & $\mathrm{RL}(\mathrm{cm})$ & $\begin{array}{l}\text { DW (g } \\
\text { plant }^{-1} \text { ) }\end{array}$ & $\begin{array}{l}\text { Pn }\left(\mu \mathrm{mol} \mathrm{m}{ }^{-2}\right. \\
\left.\mathrm{s}^{-1}\right)\end{array}$ & $\begin{array}{l}\operatorname{Tr}\left(\mathrm{mmol} \mathrm{m}^{-2}\right. \\
\left.\mathrm{s}^{-1}\right)\end{array}$ & $\begin{array}{l}\text { Gs }(\mu \mathrm{mol} \\
\left.\mathrm{mmol}^{-1}\right)\end{array}$ & $\begin{array}{l}\text { WUE }(\mu \mathrm{mol} \\
\left.\mathrm{mmol}^{-1}\right)\end{array}$ & $\begin{array}{l}\text { Total Chls (mg } \\
\left.\mathrm{g}^{-1} \mathrm{FW}\right)\end{array}$ & $\begin{array}{l}\text { Cars }\left(\mathrm{mg} \mathrm{g}^{-1}\right. \\
\text { FW) }\end{array}$ \\
\hline $\mathrm{W}_{72} \mathrm{CMC}_{3.2} \mathrm{BC}_{3.2}$ & $\begin{array}{l}15.53 \pm \\
0.3^{\mathrm{a}}\end{array}$ & $\begin{array}{l}11.81 \pm \\
0.83^{\mathrm{abc}}\end{array}$ & $\begin{array}{l}0.21 \pm \\
0.01^{\mathrm{a}}\end{array}$ & $7.17 \pm 0.06^{\mathrm{a}}$ & $3.79 \pm 0.16^{\mathrm{abc}}$ & $0.29 \pm 0.02^{\mathrm{ab}}$ & $1.9 \pm 0.1^{\mathrm{ab}}$ & $1.32 \pm 0.09^{\mathrm{abc}}$ & $0.41 \pm 0.03^{\mathrm{a}}$ \\
\hline $\mathrm{W}_{72} \mathrm{CMC}_{3.2} \mathrm{BC}_{0.8}$ & $\begin{array}{l}13.54 \pm \\
1.51^{\mathrm{ab}}\end{array}$ & $\begin{array}{l}12.18 \pm \\
0.1^{\mathrm{ab}}\end{array}$ & $\begin{array}{l}0.19 \pm \\
0.01^{\mathrm{ab}}\end{array}$ & $7.12 \pm 0.57^{\mathrm{a}}$ & $4.05 \pm 0.03^{\mathrm{a}}$ & $0.3 \pm 0.02^{\mathrm{a}}$ & $1.76 \pm 0.14^{\mathrm{abcd}}$ & $1.4 \pm 0.11^{\mathrm{a}}$ & $0.38 \pm 0.02^{\mathrm{ab}}$ \\
\hline $\mathrm{W}_{72} \mathrm{CMC}_{0.8} \mathrm{BC}_{3.2}$ & $\begin{array}{l}13.83 \pm \\
1.13^{\mathrm{ab}}\end{array}$ & $\begin{array}{l}12.97 \pm \\
0.31^{\mathrm{a}}\end{array}$ & $\begin{array}{l}0.19 \pm \\
0.01^{\mathrm{ab}}\end{array}$ & $\begin{array}{l}6.13 \pm \\
0.76^{\text {abcd }}\end{array}$ & $3.7 \pm 0.09^{b c d}$ & $0.21 \pm 0.02^{\text {cde }}$ & $1.66 \pm 0.2^{\mathrm{abcde}}$ & $1.32 \pm 0.1^{\mathrm{abc}}$ & $\begin{array}{l}0.33 \pm \\
0.01^{\text {cde }}\end{array}$ \\
\hline $\mathrm{W}_{72} \mathrm{CMC}_{0.8} \mathrm{BC}_{0.8}$ & $\begin{array}{l}12.58 \pm \\
0.64^{\mathrm{bc}}\end{array}$ & $\begin{array}{l}11.56 \pm \\
0.37^{\text {abcd }}\end{array}$ & $0.18 \pm 0^{\mathrm{ab}}$ & $\begin{array}{l}5.88 \pm \\
0.11^{\text {bcde }}\end{array}$ & $3.43 \pm 0.03^{\mathrm{de}}$ & $0.21 \pm 0.04^{\text {cde }}$ & $\begin{array}{l}1.72 \pm \\
0.05^{\text {abcde }}\end{array}$ & $1.2 \pm 0.07^{\text {cdef }}$ & $0.3 \pm 0.01^{\mathrm{def}}$ \\
\hline $\mathrm{W}_{48} \mathrm{CMC}_{3.2} \mathrm{BC}_{3.2}$ & $\begin{array}{l}11.84 \pm \\
0.17^{\text {bcd }}\end{array}$ & $7.38 \pm 0.53^{h i}$ & $\begin{array}{l}0.14 \pm \\
0.02^{\text {cd }}\end{array}$ & $5.24 \pm 0.14^{\mathrm{de}}$ & $2.63 \pm 0.05^{\mathrm{h}}$ & $0.19 \pm 0.01^{\mathrm{de}}$ & $1.99 \pm 0.03^{\mathrm{a}}$ & $0.94 \pm 0.04^{\mathrm{h}}$ & $\begin{array}{l}0.29 \pm \\
0.02^{\text {efg }}\end{array}$ \\
\hline $\mathrm{W}_{48} \mathrm{CMC}_{3.2} \mathrm{BC}_{0.8}$ & $\begin{array}{l}10.02 \pm \\
0.36^{\mathrm{de}}\end{array}$ & $8.34 \pm 0.4^{g h}$ & $\begin{array}{l}0.13 \pm \\
0.01^{\mathrm{cd}}\end{array}$ & $5.73 \pm 0.47^{\text {cde }}$ & $3.23 \pm 0.13^{\mathrm{efg}}$ & $0.22 \pm 0.02^{\text {cde }}$ & $1.79 \pm 0.21^{\mathrm{abcd}}$ & $1.09 \pm 0.01^{\mathrm{efg}}$ & $\begin{array}{l}0.29 \pm \\
0.01^{\text {efg }}\end{array}$ \\
\hline $\mathrm{W}_{48} \mathrm{CMC}_{0.8} \mathrm{BC}_{3.2}$ & $\begin{array}{l}10.21 \pm \\
0.58^{\mathrm{de}}\end{array}$ & $6.46 \pm 0.53^{\mathrm{i}}$ & $\begin{array}{l}0.12 \pm \\
0.01^{\mathrm{d}}\end{array}$ & $5.05 \pm 0.1^{\mathrm{e}}$ & $3.48 \pm 0.03^{\text {cde }}$ & $0.21 \pm 0.02^{\text {cde }}$ & $1.45 \pm 0.03^{\mathrm{de}}$ & $1.16 \pm 0.03^{\text {defg }}$ & $0.27 \pm 0.01^{\mathrm{f}_{8}}$ \\
\hline $\mathrm{W}_{48} \mathrm{CMC}_{0.8} \mathrm{BC}_{0.8}$ & $\begin{array}{l}8.96 \pm \\
0.29^{\text {ef }}\end{array}$ & $7.42 \pm 0.14^{\mathrm{hi}}$ & $\begin{array}{l}0.12 \pm \\
0.01^{\mathrm{d}}\end{array}$ & $5.4 \pm 0.03^{\text {cde }}$ & $3.66 \pm 0.06^{\mathrm{cd}}$ & $0.21 \pm 0.03^{\text {cde }}$ & $1.48 \pm 0.03^{\text {cde }}$ & $1.09 \pm 0.01^{\mathrm{efg}}$ & $0.26 \pm 0^{\mathrm{fg}}$ \\
\hline $\mathrm{W}_{80} \mathrm{CMC}_{2} \mathrm{BC}_{2}$ & $\begin{array}{l}14.96 \pm \\
1.05^{\mathrm{a}}\end{array}$ & $\begin{array}{l}10.85 \pm \\
0.09^{\text {bcde }}\end{array}$ & $0.21 \pm 0^{\mathrm{a}}$ & $7.09 \pm 0.4^{\mathrm{a}}$ & $3.98 \pm 0.03^{\mathrm{ab}}$ & $\begin{array}{l}0.24 \pm \\
0.01^{\text {abcd }}\end{array}$ & $1.78 \pm 0.11^{\mathrm{abcd}}$ & $1.35 \pm 0.03^{\mathrm{ab}}$ & $0.38 \pm 0.03^{\mathrm{ab}}$ \\
\hline $\mathrm{W}_{40} \mathrm{CMC}_{2} \mathrm{BC}_{2}$ & $\begin{array}{l}8.99 \pm \\
0.24^{\mathrm{ef}}\end{array}$ & $5.99 \pm 0.05^{\mathrm{ij}}$ & $\begin{array}{l}0.11 \pm \\
0.01^{\mathrm{de}}\end{array}$ & $5.21 \pm 0.3^{\mathrm{de}}$ & $3.09 \pm 0.09^{\mathrm{fg}}$ & $0.18 \pm 0.01^{\mathrm{de}}$ & $\begin{array}{l}1.69 \pm \\
0.08^{\text {abcde }}\end{array}$ & $0.94 \pm 0.04^{\mathrm{h}}$ & $0.25 \pm 0^{\mathrm{gh}}$ \\
\hline $\mathrm{W}_{60} \mathrm{CMC}_{4} \mathrm{BC}_{2}$ & $\begin{array}{l}13.56 \pm \\
0.63^{\mathrm{ab}}\end{array}$ & $\begin{array}{l}10.44 \pm \\
1.68^{\text {cde }}\end{array}$ & $\begin{array}{l}0.18 \pm \\
0.01^{\mathrm{ab}}\end{array}$ & $6.9 \pm 0.24^{\mathrm{ab}}$ & $3.7 \pm 0.03^{\mathrm{bcd}}$ & $0.27 \pm 0.01^{\mathrm{abc}}$ & $1.87 \pm 0.08^{\mathrm{ab}}$ & $1.06 \pm 0.01^{\mathrm{fgh}}$ & $0.33 \pm 0^{\text {cde }}$ \\
\hline $\mathrm{W}_{60} \mathrm{CMC}_{0} \mathrm{BC}_{2}$ & $\begin{array}{l}11.22 \pm \\
0.82^{\text {cd }}\end{array}$ & $\begin{array}{l}8.71 \pm \\
0.43^{\text {fgh }}\end{array}$ & $\begin{array}{l}0.14 \pm \\
0.01^{\mathrm{cd}}\end{array}$ & $5.62 \pm 0.19^{\text {cde }}$ & $4.02 \pm 0.01^{\mathrm{a}}$ & $0.18 \pm 0.02^{\mathrm{de}}$ & $1.4 \pm 0.05^{\mathrm{e}}$ & $1.04 \pm 0.02^{\mathrm{gh}}$ & $0.25 \pm 0^{g h}$ \\
\hline $\mathrm{W}_{60} \mathrm{CMC}_{2} \mathrm{BC}_{4}$ & $\begin{array}{l}13.39 \pm \\
0.75^{\mathrm{ab}}\end{array}$ & $\begin{array}{l}8.69 \pm \\
0.96^{\mathrm{fgh}}\end{array}$ & $\begin{array}{l}0.16 \pm \\
0.01^{\mathrm{bc}}\end{array}$ & $5.43 \pm 0.36^{\text {cde }}$ & $2.94 \pm 0.14^{\mathrm{gh}}$ & $\begin{array}{l}0.24 \pm \\
0.01^{\text {abcd }}\end{array}$ & $1.87 \pm 0.21^{\mathrm{ab}}$ & $1.25 \pm 0.01^{\mathrm{bcd}}$ & $\begin{array}{l}0.33 \pm \\
0.01^{\text {cde }}\end{array}$ \\
\hline $\mathrm{W}_{60} \mathrm{CMC}_{2} \mathrm{BC}_{0}$ & $\begin{array}{l}10.56 \pm \\
0.47^{\text {cde }}\end{array}$ & $\begin{array}{l}9.46 \pm \\
0.06^{\mathrm{efg}}\end{array}$ & $\begin{array}{l}0.16 \pm \\
0.01^{\mathrm{bc}}\end{array}$ & $\begin{array}{l}5.87 \pm \\
0.23^{\text {bcde }}\end{array}$ & $3.26 \pm 0.23^{\text {ef }}$ & $0.26 \pm 0.02^{\mathrm{abc}}$ & $1.82 \pm 0.15^{\mathrm{abc}}$ & $1.3 \pm 0.04^{\mathrm{abcd}}$ & $0.35 \pm 0^{\mathrm{bc}}$ \\
\hline $\mathrm{W}_{60} \mathrm{CMC}_{2} \mathrm{BC}_{2}$ & $\begin{array}{l}12.05 \pm \\
0.75^{\text {bcd }}\end{array}$ & $\begin{array}{l}10.22 \pm \\
0.09^{\text {cdef }}\end{array}$ & $\begin{array}{l}0.18 \pm \\
0.02^{\mathrm{ab}}\end{array}$ & $\begin{array}{l}6.37 \pm \\
0.23^{\mathrm{abc}}\end{array}$ & $3.68 \pm 0.18^{\mathrm{bcd}}$ & $0.23 \pm 0.02^{\mathrm{bcd}}$ & $1.74 \pm 0.1^{\text {abcde }}$ & $1.23 \pm 0.01^{\mathrm{bcde}}$ & $\begin{array}{l}0.34 \pm \\
0.01^{\mathrm{bcd}}\end{array}$ \\
\hline $\mathrm{W}_{60} \mathrm{CMC}_{2} \mathrm{BC}_{2}$ & $\begin{array}{l}11.97 \pm \\
1.17^{\text {bcd }}\end{array}$ & $\begin{array}{l}9.97 \pm \\
0.03^{\text {defg }}\end{array}$ & $\begin{array}{l}0.19 \pm \\
0.01^{\mathrm{ab}}\end{array}$ & $6.8 \pm 0.46^{\mathrm{ab}}$ & $\begin{array}{l}3.74 \pm \\
0.14^{\text {abcd }}\end{array}$ & $0.23 \pm 0.02^{\mathrm{bcd}}$ & $1.81 \pm 0.05^{\mathrm{abc}}$ & $1.25 \pm 0^{\mathrm{bcd}}$ & $0.35 \pm 0^{\mathrm{bc}}$ \\
\hline $\begin{array}{l}\mathrm{W}_{40} \mathrm{CMC}_{0} \mathrm{BC}_{0} \\
\quad \mathrm{CK}\end{array}$ & $7.12 \pm 0.35^{\mathrm{f}}$ & $4.76 \pm 0.08^{j}$ & $0.08 \pm 0^{\mathrm{e}}$ & $5.01 \pm 0.58^{e}$ & $3.09 \pm 0.13^{\mathrm{fg}}$ & $0.16 \pm 0.01^{\mathrm{e}}$ & $1.63 \pm 0.19^{\mathrm{bcde}}$ & $0.78 \pm 0.04^{\mathrm{i}}$ & $0.21 \pm 0^{\mathrm{h}}$ \\
\hline
\end{tabular}

conditions. The CMC was collected from a commercial feedlot. In addition, a temperature of $55{ }^{\circ} \mathrm{C}$ was maintained for at least three consecutive days to inactivate and kill pathogen microorganisms. Prior to soil amendment and analysis, CMC and BC were air-dried, crushed and sieved through a $2 \mathrm{~mm}$ mesh. The characteristics of the CMC and BC, as well as coal spoils are shown in Table S1 (Supplementary Material). All details regarding the methods used to characterize these materials are also presented in the Supplementary Material. Regarding the pot experiments, $400 \mathrm{~g}$ of coal-mined spoil was taken into polyethylene plastic pots (11.7 cm upper diameter, $13.5 \mathrm{~cm}$ height and $9.2 \mathrm{~cm}$ bottom diameter) and mixed with different levels of CMC and BC and into each pot fifty $O$. viciifolia seeds were planted. Five different water levels were used to reflect the soil water content at field capacity (FC) (i.e., $80 \% \mathrm{FC}$ $=$ highest, $72 \% \mathrm{FC}=$ high, $60 \% \mathrm{FC}=$ moderate, $48 \% \mathrm{FC}=$ low, and $40 \%$ FC = very-low dose) (Roy et al., 2021a). For both CMC and BC, 5 rates (weight/weight) were used (i.e., $4.0 \%=$ highest, $3.2 \%=$ high, $2.0 \%=$ moderate, $0.8 \%=$ low, and $0 \%=$ either no-CMC or no-BC dose). The experiment was set up using a standard response surface methodology (RSM), namely central composite design (CCD) for the optimization of the selected independent variables. Seed disinfection and germination were carried out as per Roy et al. (2021b). Seedlings were trimmed to 10 plants per pot at the $5^{\text {th }}$ true leaf stage, and then the 5 different $\mathrm{W}$ doses were applied and followed for two months. Day and night temperatures in the greenhouse were maintained at $27 \pm 1{ }^{\circ} \mathrm{C}$ and $18 \pm 1{ }^{\circ} \mathrm{C}$, respectively. Relative humidity, light intensity, and light cycle were 70 $\pm 5 \%, 150 \mathrm{~mol} \mathrm{~m}^{-2} \mathrm{~s}^{-1}$ photosynthetically active radiation, and $14 / 10 \mathrm{~h}$ (day/night), respectively. The CCD design consisted of 17 treatments, each replicated 5 times (in total $5 \times 17=85$ pots; Table 1 ; details of the computations can be found in Table S2, Supplementary Material). Here, the lowest $\mathrm{W}$ regime $\left(\mathrm{W}_{40}\right)$ and without $\mathrm{CMC}$ and $\mathrm{BC}\left(\mathrm{W}_{40} \mathrm{CMC}_{0} \mathrm{BC}_{0}\right)$ was treated as control. The $O$. viciifolia's integrated growth performance (IGP) was examined according to Roy et al. (2021a) approach (details are given in the Supplementary Appendix). All analytical-grade chemical reagents were provided by Sigma-Aldrich Trading Co., Ltd., Shanghai, China.

\subsection{Assessment of morphological growth traits}

Five seedlings selected at random from each pot were cut at the above-ground level to assess plant height $(\mathrm{PH}, \mathrm{cm})$ and maximum root length $(\mathrm{RL}, \mathrm{cm})$ with the help of a measuring tape at the end of this study. Plant biomass (dry weight, DW, $g_{\text {plant }}{ }^{-1}$ ) was the sum of leaf, stem and root mass and was measured following Roy et al. (2021b).

\subsection{Assessments of physiological and biochemical components, and} antioxidant enzyme activities in $O$. viciifolia leaves

Net photosynthesis rate ( $\mathrm{Pn}, \mu \mathrm{mol} \mathrm{m} \mathrm{m}^{-2} \mathrm{~s}^{-1}$ ), stomatal conductance (Gs, $\left.\mu \mathrm{mol} \mathrm{mmol}^{-1}\right)$, transpiration rate $\left(\mathrm{Tr}, \mathrm{mmol} \mathrm{m}^{-2} \mathrm{~s}^{-1}\right.$ ) and water use

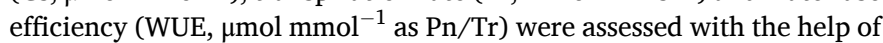
CIRAS-3 portable photosynthesis system (Amesbury, MA, USA). The concentration of total chlorophyll (TChls) ( $\mathrm{mg} \mathrm{g}^{-1}$ fresh weight (FW)) and carotenoids (Cars) $\left(\mathrm{mg} \mathrm{g}^{-1} \mathrm{FW}\right)$ were estimated in accordance with our previous study (Roy et al., 2020a).

The relative water content (RWC, \%) and membrane stability index (MSI, \%) of $O$. viciifolia leaves were assessed using previously described methods (Roy et al., 2020c). For measuring the malondialdehyde (MDA, $\left.\mu \mathrm{mol} \mathrm{g}{ }^{-1} \mathrm{FW}\right)$, hydrogen peroxide $\left(\mathrm{H}_{2} \mathrm{O}_{2}, \mu \mathrm{mol} \mathrm{g}{ }^{-1} \mathrm{FW}\right)$ and superoxide anion $\left(\mathrm{O}_{2}{ }^{{ }^{-}}\right.$, nmol $\left.\mathrm{min}^{-1} \mathrm{~g}^{-1} \mathrm{FW}\right)$ contents, the methods described by Roy et al. (2020b), Velikova et al. (2000) and Ke et al. (2002), 


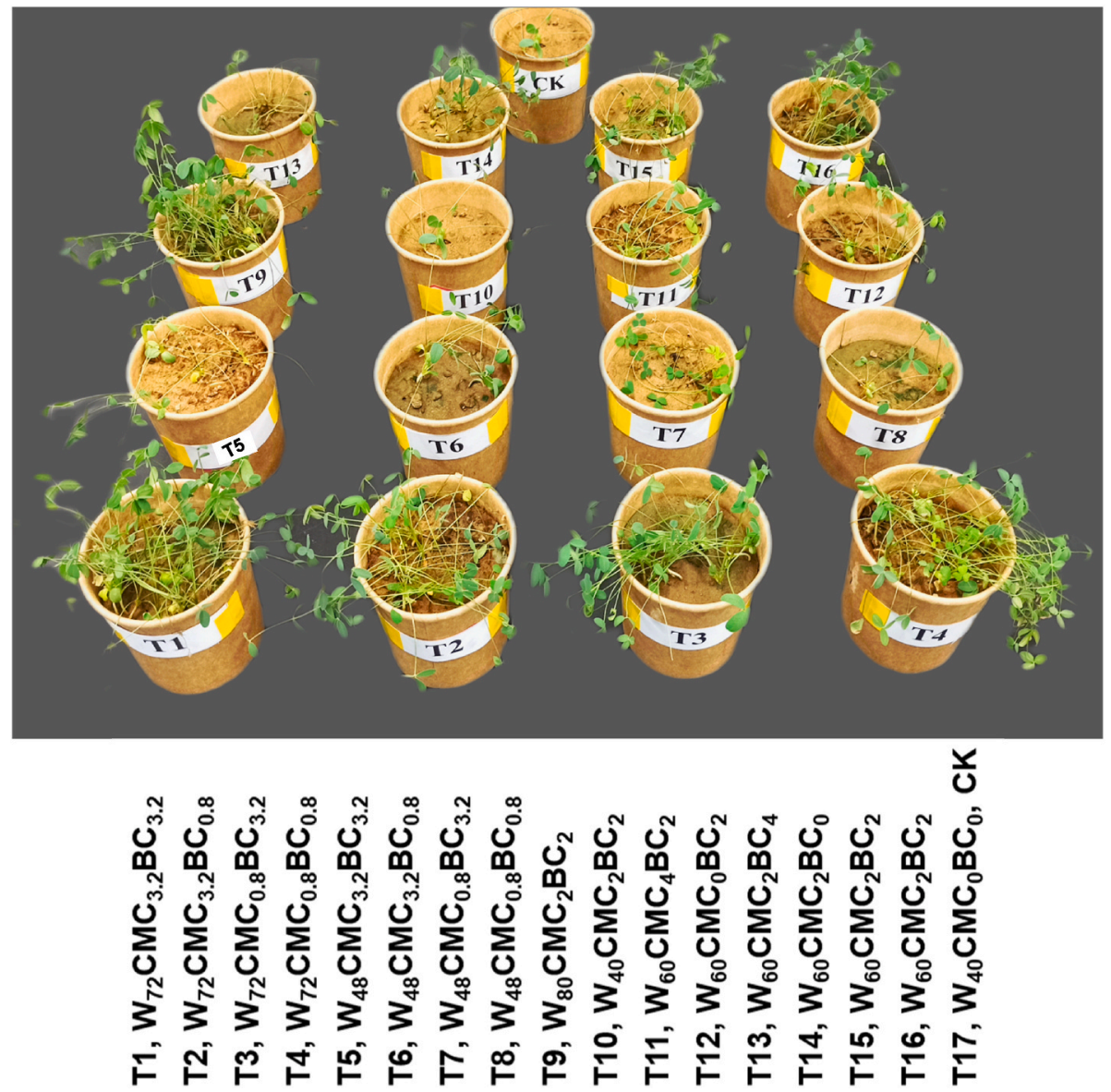

Fig. 1. The effects of various regimes of water-cattle manure compost-wood biochar (W-CMC-BC) on phenotypic traits of $O$. viciifolia.

respectively, were used. For proline (Pro, $\mu \mathrm{mol} \mathrm{g}^{-1} \mathrm{FW}$ ) and total soluble sugar contents (SS, $\mathrm{mg} \mathrm{g}^{-1} \mathrm{FW}$ ) determination, sulphosalicylic acid and anthrone- $\mathrm{H}_{2} \mathrm{SO}_{4}$ methods, respectively, were used (Bates et al., 1973; Joseph, 1955). Antioxidant enzyme activities of superoxide dismutase (SOD, $\mathrm{U} \mathrm{g}^{-1} \mathrm{FW}$ ), catalase (L-CAT, $\mathrm{U} \mathrm{min}^{-1} \mathrm{~g}^{-1} \mathrm{FW}$ ), peroxidase (POD,

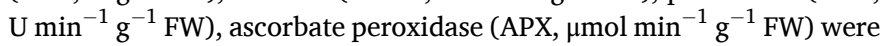
estimated according to our previous study (Roy et al., 2021c).

\subsection{Estimation of soil physical, chemical and enzyme activities}

Bulk density $\left(\mathrm{g} \mathrm{cm}^{-3}\right)$ was determined by 'core cutter method' (SAA, 1977). The soil water holding capacity (WHC, \%) was measured according to Ogbaga et al. (2014). In brief, weight was taken of fully water-saturated soil after draining it for 2-3 days. After that the soil sample was oven dried at $105{ }^{\circ} \mathrm{C}$ to get a constant weight. The weight difference between water-saturated and oven-dried soil was taken as the weight of water needed to bring pots $100 \% \mathrm{FC}$, and different FC were calculated accordingly. The available nitrogen (Avail- $\mathrm{N}, \mathrm{NH}_{4}{ }^{+}-\mathrm{N}$ and $\mathrm{NO}_{3}{ }^{-} \mathrm{N}, \mathrm{mg} \mathrm{kg}^{-1}$ ) was determined by extracting $10 \mathrm{~g}$ of fresh soil with $50 \mathrm{~mL}$ of $2 \mathrm{M} \mathrm{KCl}$ and measuring it in a continuous-flow ion autoanalyzer (Scalar SAN ${ }^{\text {plus }}$ segmented flow analyzer, Netherlands) (Lu, 2000). The Olsen soil P test was used to extract soil available phosphorus (Avail-P, mg kg ${ }^{-1}$ ) using $0.5 \mathrm{~mol} \mathrm{~L}^{-1} \mathrm{NaHCO}_{3}$ at pH 8.5 (Lu, 2000). Soil available potassium (Avail- $\mathrm{K}, \mathrm{mg} \mathrm{kg}^{-1}$ ) was extracted and quantified using $1 \mathrm{~mol} \mathrm{~L}^{-1} \mathrm{NH}_{4} \mathrm{OAc}$ and a PerkinElmer Pin AAcle $900 \mathrm{~F}$ Atomic Absorption Spectrometer (Waltham, MA, USA), respectively (Lu, 2000). The soil urease ( $\mathrm{mg} \mathrm{g}^{-1} \mathrm{~d}^{-1}$ ) activity was analyzed using the methods described by Guan (1986) . The soil catalase (S-CAT, $\mathrm{mg} \mathrm{g}^{-1} \mathrm{~d}^{-1}$ ) activity was assessed as described by Hopkins et al. (1996).

\subsection{Data analysis}

The analysis of variance (ANOVA) was used to evaluate the individual and interaction impacts of three independent variables (W, CMC and $\mathrm{BC}$ ) on various response variables, as well as the estimate of coefficients. The numerical data presented in the tables and figures are means \pm standard errors (SEs) of five replicates for each treatment. Optimum W-CMC-BC rate was identified by applying Derringer's desired function approach with the help of Design Expert statistical software (version 11.0, Stat-Ease, Inc., Minneapolis, MN, USA). Pearson's correlation coefficients were presented in the form of a matrix of correlations. Heatmap was produced employing ClustVis version 2.0 (https://biit.cs.ut.ee/clustvis) (Roy et al., 2020b).

\section{Results}

The application of $\mathrm{W}, \mathrm{CMC}$ and $\mathrm{BC}$ resulted in a significant increase $(p<0.05)$ in plant height $(\mathrm{PH})$, maximum root length $(\mathrm{RL})$ and dry biomass (DW) in all the experimental treatments (except $\mathrm{W}_{40} \mathrm{CMC}_{2} \mathrm{BC}_{2}$ ) over the control (Table 2; Fig. 1). The maximum increases in $\mathrm{PH}$ and DW were observed under $\mathrm{W}_{72} \mathrm{CMC}_{3.2} \mathrm{BC}_{3.2}$ treatment. Here $\mathrm{PH}$ and $\mathrm{DW}$ were $118 \%$ and $163 \%$ greater, respectively, over the control (Table 2). The $\mathrm{W}_{40} \mathrm{CMC}_{2} \mathrm{BC}_{2}$ treatment, on the other hand, did not cause any significant differences (Table 2; Fig. 1).

Seedlings exposed to $\mathrm{W}_{72} \mathrm{CMC}_{3.2} \mathrm{BC}_{3.2}, \mathrm{~W}_{72} \mathrm{CMC}_{3.2} \mathrm{BC}_{0.8}$ and $\mathrm{W}_{80} \mathrm{CMC}_{2} \mathrm{BC}_{2}$ showed a significant increase $(p<0.05)$ in net photosynthesis rate (Pn) (by 43, 42 and $42 \%$, respectively), stomatal conductance (Gs) (by 81,88 and 50\%, respectively), and transpiration rate (Tr) (by 23, 31 and 29\%, respectively) (Table 2). Leaf water use efficiency (WUE) increased by the most $(+22 \%$ over control) under the 

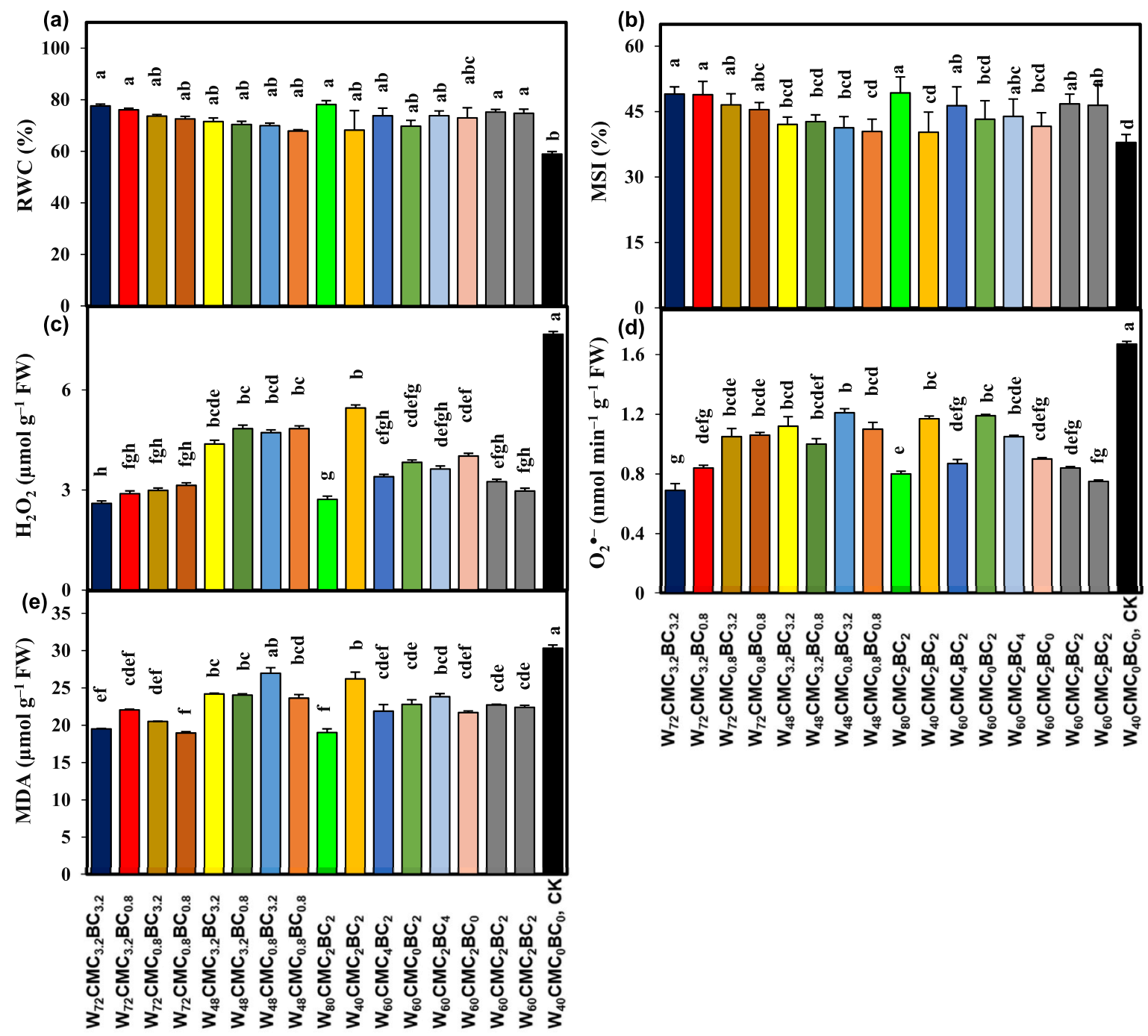

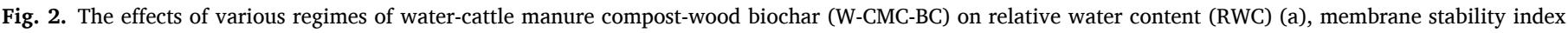

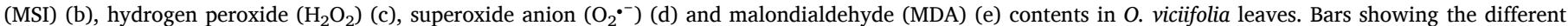
letters are significantly different $(p<0.05)$ according to LSD test. Each value represents the mean of 5 replications \pm SEs.

$\mathrm{W}_{48} \mathrm{CMC}_{3.2} \mathrm{BC}_{3.2}$ treatment (Table 2). The W-CMC-BC application resulted in a significant increase $(p<0.05)$ in total chlorophyll (TChls) and carotenoids (Cars) content of all experimental treatments over the control (Table 2). Specifically, treatments $\mathrm{W}_{72} \mathrm{CMC}_{3.2} \mathrm{BC}_{3.2}$, $\mathrm{W}_{72} \mathrm{CMC}_{3.2} \mathrm{BC}_{0.8}$ and $\mathrm{W}_{80} \mathrm{CMC}_{2} \mathrm{BC}_{2}$ remarkably increased TChls content by 69,79 , and $73 \%$, and Cars content by 95,81 , and $81 \%$, compared to control (Table 2). Plants under the same treatments also increased RWC by 32,29 and $33 \%$, and MSI by 29,29 and $30 \%$, respectively, compared to control (Fig. 2a and b). The W-CMC-BC application resulted in a significant decrease $(p<0.05)$ in $\mathrm{H}_{2} \mathrm{O}_{2}, \mathrm{O}_{2}{ }^{-}$, MDA, Pro and SS contents in all the experimental treatments, which were $30-67 \%, 29-60 \%$, $12-38 \%, 14-63 \%$ and $17-61 \%$ lower, respectively, over the control (Fig. 2c-e; Fig. 3a and b). However, seedlings exposed to moderate to highest-W doses $(\geq 60 \% \mathrm{FC})$ like $\mathrm{W}_{72} \mathrm{CMC}_{3.2} \mathrm{BC}_{3.2}, \mathrm{~W}_{72} \mathrm{CMC}_{3.2} \mathrm{BC}_{0.8}$, $\mathrm{W}_{72} \mathrm{CMC}_{0.8} \mathrm{BC}_{3.2}, \mathrm{~W}_{72} \mathrm{CMC}_{0.8} \mathrm{BC}_{0.8}, \mathrm{~W}_{80} \mathrm{CMC}_{2} \mathrm{BC}_{2}$ and $\mathrm{W}_{60} \mathrm{CMC}_{2} \mathrm{BC}_{2}$ showed greater decrease in MDA contents compared to seedlings exposed to very low-to low-W doses, regardless of CMC and $\mathrm{BC}$ additions (Fig. 2e).

Activities of SOD, CAT, POD and APX in the leaves of $O$. viciifolia radically increased over control when seedlings were exposed to very low-to low-W regimes together with different $\mathrm{CMC}$ and $\mathrm{BC}$ doses (Fig. 3c-f). Therefore, seedlings treated with $\mathrm{W}_{48} \mathrm{CMC}_{3.2} \mathrm{BC}_{3.2}$, $\mathrm{W}_{48} \mathrm{CMC}_{3.2} \mathrm{BC}_{0.8}, \mathrm{~W}_{48} \mathrm{CMC}_{0.8} \mathrm{BC}_{3.2}, \mathrm{~W}_{48} \mathrm{CMC}_{0.8} \mathrm{BC}_{0.8}$ and $\mathrm{W}_{40} \mathrm{CMC}_{2} \mathrm{BC}_{2}$ significantly increased SOD activity by 18, 14, 13, 23 and 17\%, CAT activity by $18,27,37,32$ and $22 \%$, POD activity by $22,23,13,24$ and $26 \%$, and APX activity by 52, 45, 62, 61 and 59\%, respectively, compared with control (Fig. 3c-f).

All combinations of treatments except $\mathrm{W}_{48} \mathrm{CMC}_{0.8} \mathrm{BC}_{0.8}$, $\mathrm{W}_{60} \mathrm{CMC}_{0} \mathrm{BC}_{2}$ and $\mathrm{W}_{60} \mathrm{CMC}_{2} \mathrm{BC}_{0}$ significantly increased $(p<0.05)$ soil water holding capacity (WHC) over that of control treatment (Fig. 4a). In the soil, the available $\mathrm{N}$ (Avail- $\mathrm{N}$ ) content also significantly increased $(p<0.05) \quad$ (except $\quad \mathrm{W}_{48} \mathrm{CMC}_{3.2} \mathrm{BC}_{0.8}, \quad \mathrm{~W}_{48} \mathrm{CMC}_{0.8} \mathrm{BC}_{0.8}$ and $\mathrm{W}_{40} \mathrm{CMC}_{2} \mathrm{BC}_{2}$ ), than those of control treatment (Fig. $4 \mathrm{~b}$ ). The available $\mathrm{P}$ (Avail-P) content was significantly higher $(p<0.05)$ in the various treatments (except $\mathrm{W}_{48} \mathrm{CMC}_{0.8} \mathrm{BC}_{0.8}$ ) over control (Fig. $4 \mathrm{c}$ ). The application of W-CMC-BC resulted in a significant increase $(p<0.05)$ in available $\mathrm{K}$ (Avail-K) content in all the treatments compared with control. The highest increase in Avail-K content was observed under $\mathrm{W}_{72} \mathrm{CMC}_{3.2} \mathrm{BC}_{3.2}$, which was 4.3 times higher than that of control treatment (Fig. 4d). Soil enzyme activities such as urease and catalase (SCAT) significantly increased $(p<0.05)$ over control when seedlings were exposed to $\mathrm{W}$ regime ( $\geq 60 \% \mathrm{FC}$ ) together with different $\mathrm{CMC}$ and $\mathrm{BC}$ doses (Fig. $4 \mathrm{e}$ and $\mathrm{f}$ ). Conversely, the $\mathrm{W}_{48} \mathrm{CMC}_{3.2} \mathrm{BC}_{3.2}$, $\mathrm{W}_{48} \mathrm{CMC}_{3.2} \mathrm{BC}_{0.8}, \mathrm{~W}_{48} \mathrm{CMC}_{0.8} \mathrm{BC}_{3.2}, \mathrm{~W}_{48} \mathrm{CMC}_{0.8} \mathrm{BC}_{0.8}$ and $\mathrm{W}_{40} \mathrm{CMC}_{2} \mathrm{BC}_{2}$ treatments did not cause any significant differences (Fig. $4 \mathrm{e}$ and $\mathrm{f}$ ).

The positive and negative values of the coefficients $\beta_{1}, \beta_{2}$ and $\beta_{3}$ 

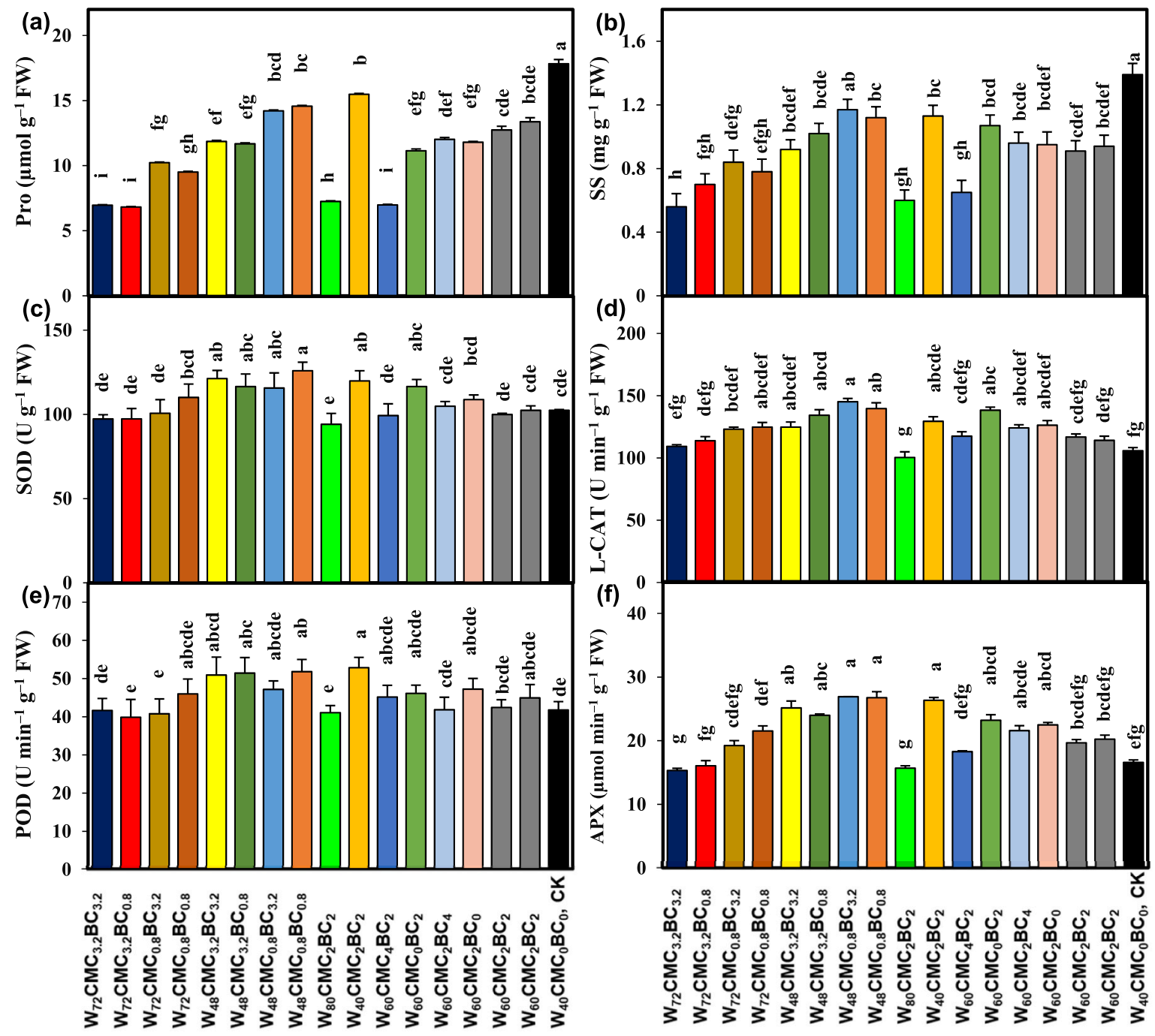

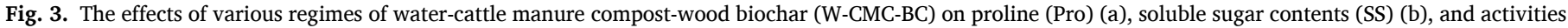

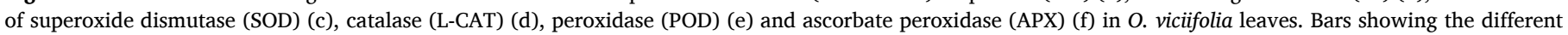
letters are significantly different $(p<0.05)$ according to LSD test. Each value represents the mean of 5 replications \pm SEs.

(Table S3) indicates the synergistic and antagonistic effect of W, CMC and $\mathrm{BC}$ doses on the different growth attributes of $O$. viciifolia.

\subsection{Assessment of multiple growth response of O. viciifolia exposed to different combinations of W-CMC-BC by correlation studies and heatmap approach}

A Pearson's correlation coefficient analysis was performed to quantify the relationships between different plant and soil parameters under a variety of W-CMC-BC treatments (Fig. 5a). Gas exchange traits, photosynthetic pigment concentrations were all favorably correlated with diverse morphological growth parameters like PH, RL, and DW. However, morphological growth parameters were negatively correlated with ROS, MDA contents, and antioxidant enzyme activities. It was also observed that plant growth parameters were positively corelated with soil water and nutrient contents and enzyme activities (Fig. 5a).

The heatmap analysis (Fig. 5b) revealed two considerable clusters that corresponded to the $\mathrm{W}_{60} \mathrm{CMC}_{2} \mathrm{BC}_{4}, \quad \mathrm{~W}_{72} \mathrm{CMC}_{0.8} \mathrm{BC}_{0.8}$, $\mathrm{W}_{72} \mathrm{CMC}_{0.8} \mathrm{BC}_{3.2}, \quad \mathrm{~W}_{60} \mathrm{CMC}_{2} \mathrm{BC}_{2}, \quad \mathrm{~W}_{60} \mathrm{CMC}_{4} \mathrm{BC}_{2}, \quad \mathrm{~W}_{72} \mathrm{CMC}_{3.2} \mathrm{BC}_{0.8}$, $\mathrm{W}_{72} \mathrm{CMC}_{3.2} \mathrm{BC}_{3.2}, \mathrm{~W}_{80} \mathrm{CMC}_{2} \mathrm{BC}_{2}$ on the left, because of their lower levels of antioxidant enzyme activities, osmolytes, ROS and MDA, but higher levels of soil water and nutrient contents and soil enzyme activities, leaf gas exchange attributes, photosynthetic pigment concentrations, water status, morphological growth attributes. However, the rest of the treatments $\quad\left(\mathrm{W}_{40} \mathrm{CMC}_{2} \mathrm{BC}_{2}, \quad \mathrm{~W}_{48} \mathrm{CMC}_{3.2} \mathrm{BC}_{0.8}, \quad \mathrm{~W}_{48} \mathrm{CMC}_{0.8} \mathrm{BC}_{0.8}\right.$, $\mathrm{W}_{48} \mathrm{CMC}_{0.8} \mathrm{BC}_{3.2}, \mathrm{~W}_{40} \mathrm{CMC}_{0} \mathrm{BC}_{0}, \mathrm{~W}_{60} \mathrm{CMC}_{0} \mathrm{BC}_{2}, \mathrm{~W}_{48} \mathrm{CMC}_{3.2} \mathrm{BC}_{3.2}$ and $\mathrm{W}_{60} \mathrm{CMC}_{2} \mathrm{BC}_{0}$ ) were assembled on the right side because of their higher amounts of ROS, MDA and activities of antioxidant enzyme and lower levels of morphological growth attributes, soil water and nutrient contents and enzyme activities (Fig. 5b).

\subsection{Interactive effects of $W, C M C$ and $B C$ on IGP of $O$. viciifolia and their optimization}

O. viciifolia seedlings subjected to $\mathrm{W}_{72} \mathrm{CMC}_{3.2} \mathrm{BC}_{3.2}$ and control showed highest and lowest IGP of 0.77 and 0.23 , respectively (Table S4, Supplementary Material). As seen in Fig. $6 \mathrm{a}$ and b, O. viciifolia's IGP improved when CMC and BC were increased to moderate levels, but thereafter showed a diminishing tendency when additional increases in CMC and BC are attempted. The IGP of $O$. viciifolia, on the other hand, rose consistently with increasing $\mathrm{W}$ doses.

To pick the optimal W-CMC-BC dose, we preserved DW, RL, PH, Pn, WUE, Gs, TChls, Cars, MSI, RWC, SS, Pro, SOD, L-CAT, APX, POD, WHC, Avail-N, Avail-P, Avail-K, Urease and S-CAT at their higher level. In opposite, $\mathrm{H}_{2} \mathrm{O}_{2}, \mathrm{O}_{2} .^{-}$and MDA were preserved at their lower level (Fig. 6c). At last, the RSM determined the optimal combinations to be 

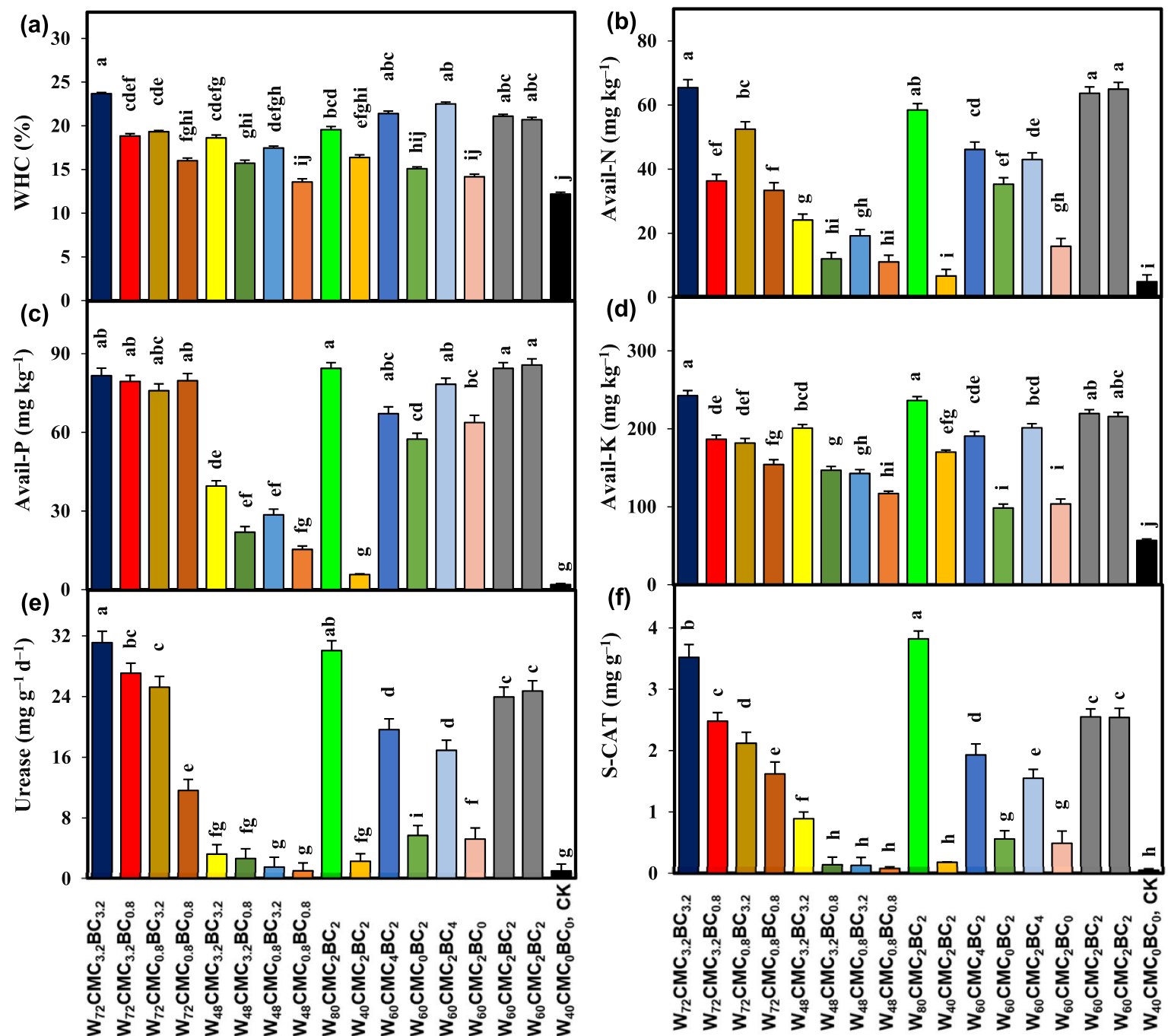

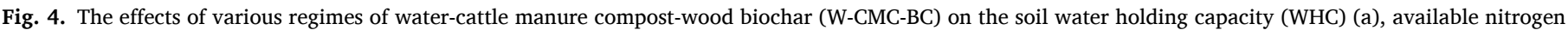

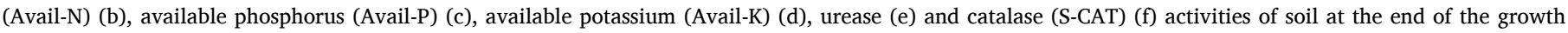
period. Bars showing the different letters are significantly different $(p<0.05)$ according to LSD test. Each value represents the mean of 5 replications \pm SEs.

the following: $\mathrm{W}$ of $64.0 \% \mathrm{FC}, \mathrm{CMC}$ of $2.4 \%$ and $\mathrm{BC}$ of $1.7 \%$, respectively (Fig. 6c).

Table S5 summarizes the multiple modelling equations, all of which include coded variables to describe growth responses (Supplementary Material). Results from ANOVA exhibited that statistical regression models for the various growth parameters are statistically significant. Excellent correlation between the projected and practical values indicates that the RSM approach is trustworthy (Table S5).

\section{Discussion}

Coal mine spoils was drought prone and low in nutrient content, which was unsuitable for plant growth (Table S1). However, in this study we observed that drought tolerant $O$. viciifolia could grow well on coal mine spoils (Table 2). Our study exhibited that maximum growth attributes such as plant height, maximum root length and biomass were attained at moderate to highest $\mathrm{W}$ regimes, and application of CMC and BC positively enhanced growth associated attributes of $O$. viciifolia even at low-W regime but not at very low-W regime (Fig. 1; Table 2). As an organic matter-rich amendment, CMC increases infiltration, decreases evaporation, and captures water for plant use. Moreover, CMC aids in plant rooting and nutrient uptake when conditions are harsh (Dimkpa et al., 2020). In addition, biochar increases water and nutrients availability in the soil as well as improves its physical and chemical properties, which can influence plant growth and change the state of soil and the environment (Xie et al., 2021). Numerous previous studies have shown that biochar produced at low temperature $\left(<550{ }^{\circ} \mathrm{C}\right)$ pyrolysis contains more labile organic matter as well as key macronutrients for plant growth and is thus widely used as soil amendment on soil fertility viewpoint (Al-Wabel et al., 2013; Joseph et al., 2010; Keiluweit et al., 2010; Luo et al., 2018).

Among plant physiological processes, photosynthesis is the most vital and important process for plant growth (Gururani et al., 2013). In our study, gas exchange traits and photosynthetic pigment content of $O$. viciifolia significantly declined under $\mathrm{W}$-shortage conditions, while photosynthetic traits showed positive responses to $\mathrm{W}, \mathrm{CMC}$ and $\mathrm{BC}$ supplies (Table 2). Drought stress has reduced net photosynthesis and chlorophyll concentrations in most cases (Cechin et al., 2006). It may be caused by chemical signals produced by the roots, as well as a decrease in leaf water content because of water shortages that cause stomatal closure and declined stomatal conductance (Table 2). Manure and biochar, however, prevent stomatal closure under stress conditions due to adequate ventilation, appropriate drainage, high porous texture and water storage, and improve the carbon dioxide needed for photosynthesis (Abideen et al., 2020), as also noticed in our current study.

In our study, the leaf relative water content (RWC) and membrane 
(a) $\mathrm{PH}$

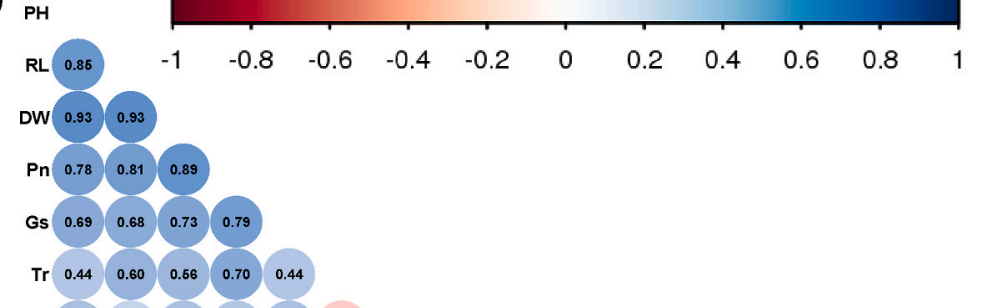

$\begin{array}{llllllll}\text { WUE } & 0.49 & 0.32 & 0.47 & 0.42 & 0.49 & -0.34\end{array}$

TChls $0.74 \quad 0.82 \quad 0.84 \quad 0.69 \quad 0.76 \quad 0.66 \quad 0.21$

$\begin{array}{lllllllll}\text { Cars } & 0.86 & 0.81 & 0.92 & 0.87 & 0.88 & 0.44 & 0.80 & 0.86\end{array}$

RWC $0.90 \quad 0.92 \quad 0.93 \quad 0.79 \quad 0.76 \quad 0.46 \quad 0.49 \quad 0.86 \quad 0.92$

$\begin{array}{lllllllllll}\text { MSI } & 0.92 & 0.90 & 0.96 & 0.92 & 0.72 & 0.65 & 0.40 & 0.73 & 0.88 & 0.89\end{array}$

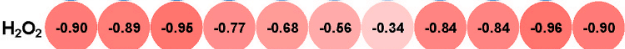

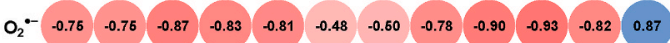

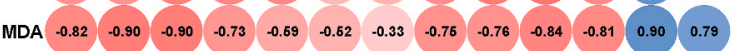

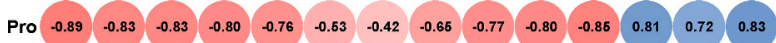

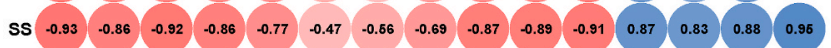

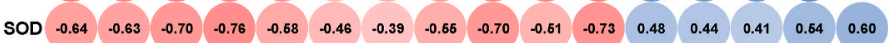

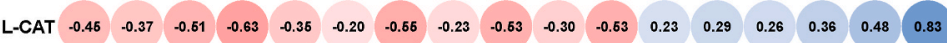

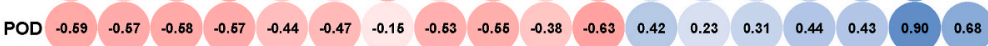

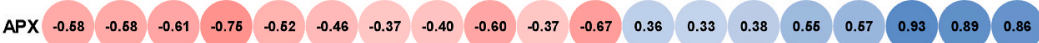

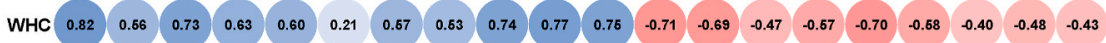

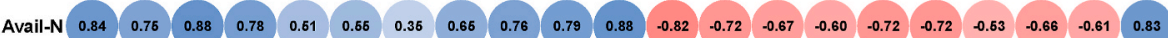

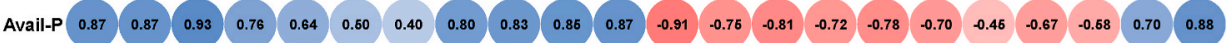

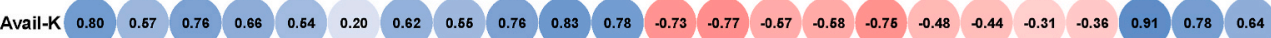

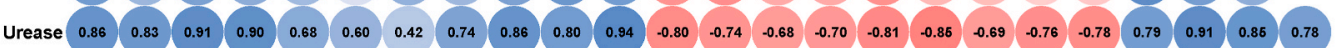

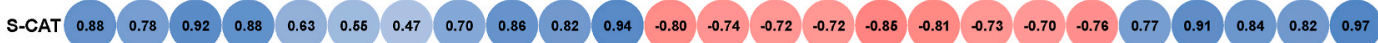

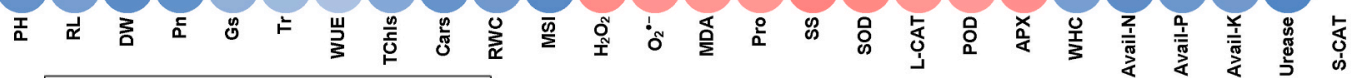

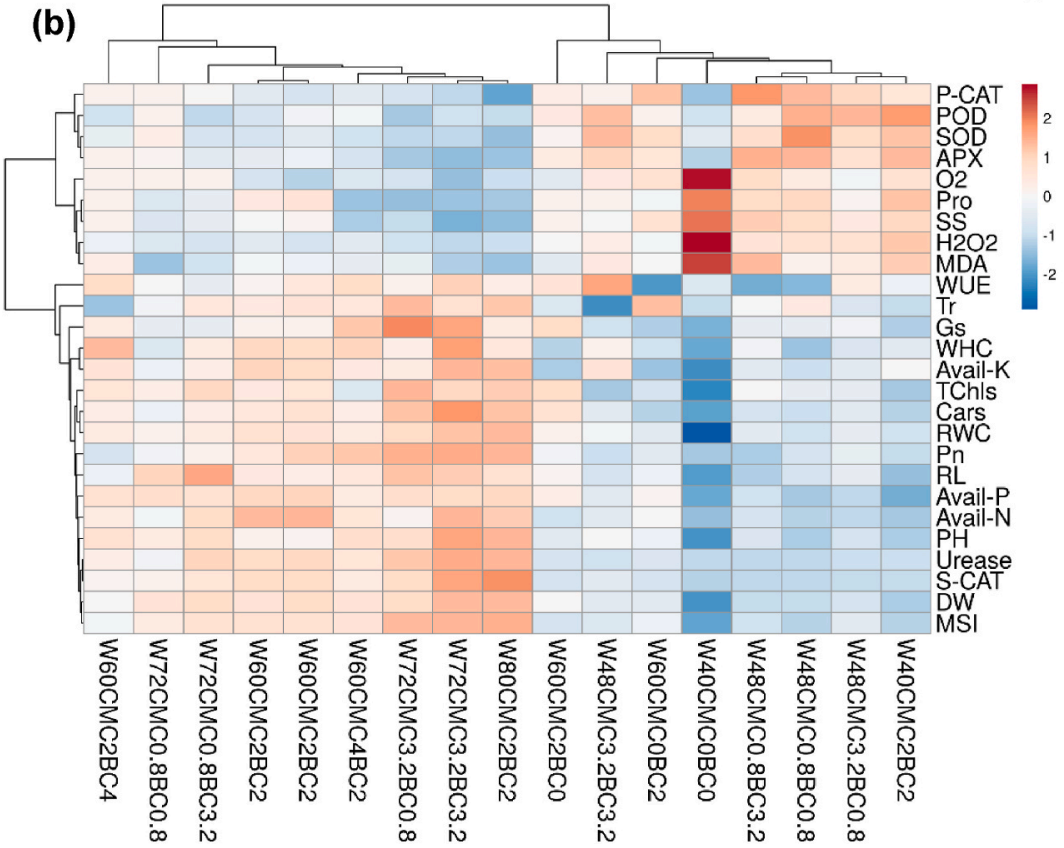

Plant height

Root length

Plant dry weight

Net photosynthesis rate

Stomatal conductance

Transpiration rate

Water use efficiency

Total Chlorophylls

Carotenoids

relative water content

Leaf membrane stability index

peroxide anion

Proline

Soluble sugars

Superoxide dismutase activity

Leaf's catalase activity

Peroxidase activity

Ascorbate peroxidase

Available Nitrogen

able Phosphorus

Urease activity

Soil catalase activity

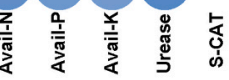

Plant height

Root length

Plant dry weight

Net photosynthesis rate

Stomatal conductance

Transpiration rate

Water use efficiency

Total Chlorophylls

Carotenoids

Leaf relative water content

Leaf membrane stability index

Hydrogen peroxide content

Superoxide anion

Malondialdehyde content

Proline

Soluble sugars

Superoxide dismutase activity

Leaf's catalase activity

Peroxidase activity

Ascorbate peroxidase

Water holding capacity

Available Nitrogen

Available Phosphorus

Available Potassium

Urease activity

Soil catalase activity

Fig. 5. Pearson's correlation coefficient (a) and heatmap (b) showing the interaction effect of water-cattle manure compost-wood biochar (W-CMC-BC) on the various growth responses of $O$. viciifolia. 

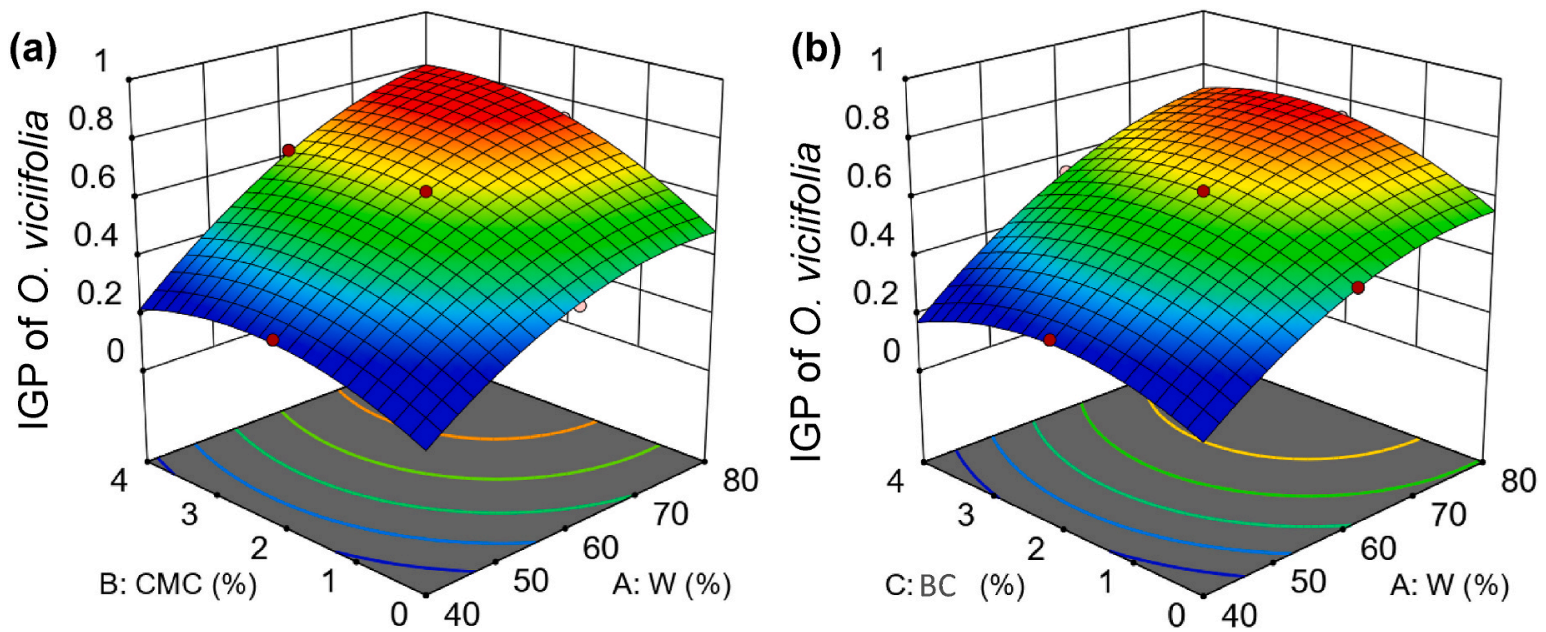

(c)
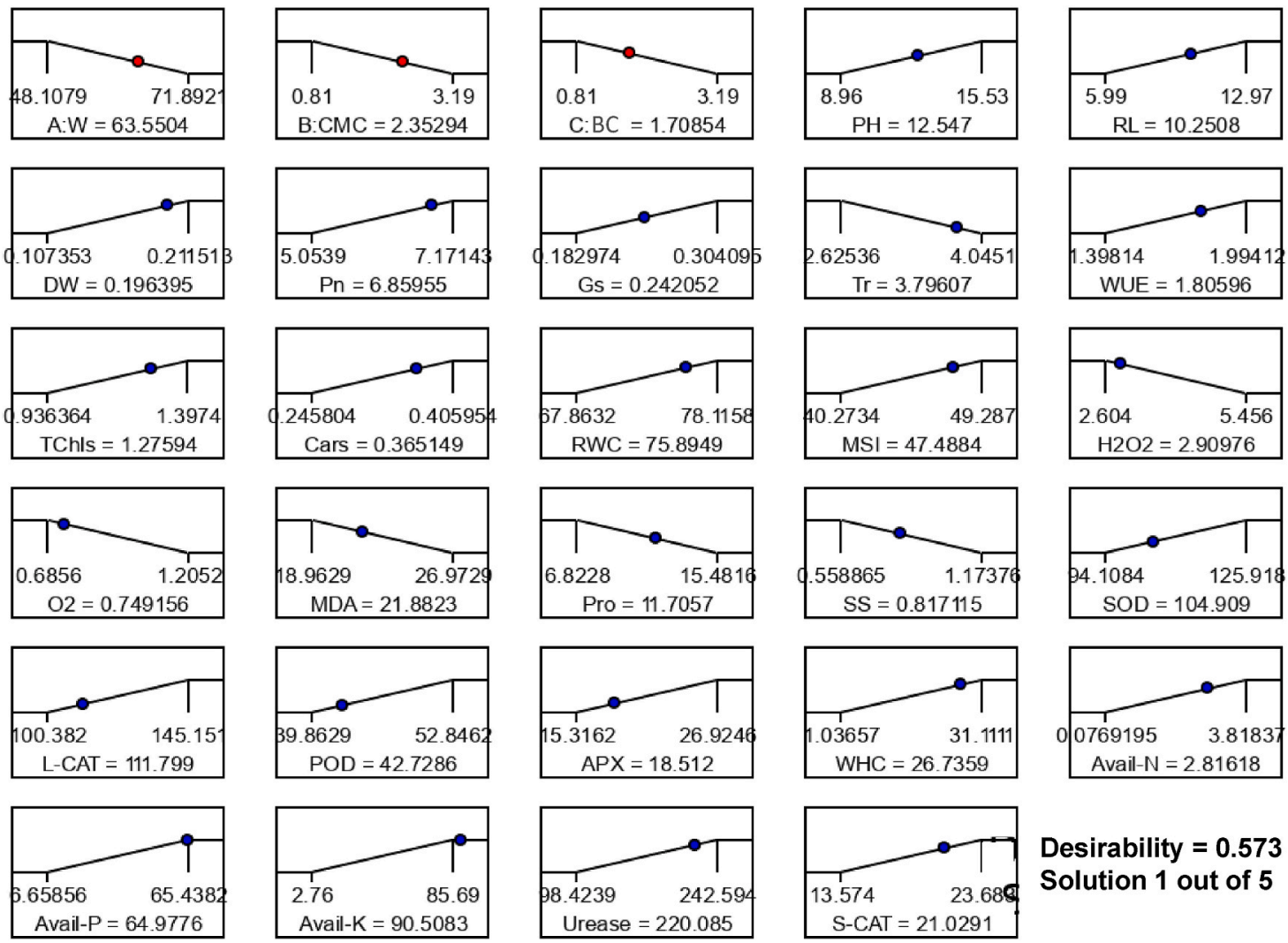

Desirability $=0.573$
Solution 1 out of 5

Fig. 6. Response surface plots (a-b) indicating integrated growth performance (IGP) of $O$. viciifolia and desirability ramp (c) for optimization.

stability index (MSI) dramatically declined under W-shortage conditions (Fig. 2a and b). The decline of RWC and MSI in the leaves under very low-W regime, as well as the subsequent growth retardation, are indicators of turgor pressure deficits, which limit cell expansion and enlargement (Kumar and Sharma, 2010). However, CMC and BC showed their potential by increasing RWC and MSI even at low W content. This could be due to the positive effect of manure and biochar on enhancing soil water content, which is closely connected to the enrichment of plant-available water (Abideen et al., 2020). Kheirizadeh Arough et al. (2016) also mentioned that application of organic fertilizer under water shortage conditions increased the leaf water content. However, the improvement of RWC by organic fertilizer treatments can be due to the increase of soluble sugar content, as reported by Rao et al. (2007). In addition, Salehi et al. (2016) stated that higher soluble sugar content in bio-fertilized leaves might be due to enhanced RWC and reduced chlorophyll photo-oxidation activity. However, in our study, proline (Pro) content was significantly declined, and total chlorophyll (TChls) content was considerably enhanced by the application of CMC and BC (Fig. 3a; Table 2). This may be due to both Pro and TChls content being produced from the same precursor (glutamate) (Gomes Silveira et al., 2003), and Pro content was reduced by the CMC and BC treatments (Fig. 3a) to improve chlorophyll synthesis in plant leaves (Table 2). Our experimental results were also supported by previous research stating that fertilizer application significantly reduced leaf Pro content and increased TChl content (Salehi et al., 2016).

Our results revealed that $\mathrm{W}$ shortage causes oxidative damage, as proved by high levels of malondialdehyde (MDA) by increasing the production of ROS such as $\mathrm{H}_{2} \mathrm{O}_{2}$ and $\mathrm{O}_{2}{ }^{-}$contents in leaves of 
O. viciifolia (Fig. 2c-e). Although a small amount of $\mathrm{H}_{2} \mathrm{O}_{2}$ is helpful, high levels of $\mathrm{H}_{2} \mathrm{O}_{2}$ cause membrane damage and cell death in plants (Das and Roychoudhury, 2014). Application of CMC and BC increases the antioxidant enzyme activities like SOD, CAT, POD and APX, suggesting this to be a response mechanism that could enhance drought tolerance (Fig. 3c-f). Increased antioxidant enzyme activities stimulate the immune system, remove excess ROS and reduce the negative effect of water shortage on different plant species (Roy et al., 2020b, 2021b, 2020b).

One of the most obvious effects of organic manure and biochar addition to soils is an increase of soil water holding capacity, which is likely to be connected to increases in plant-available water (Verheijen et al., 2019). Abideen et al. (2020) reported that the use of biochar lead to consistently enhance plant water availability, even in sandy loam soils. Moreover, it was also found that optimum biochar and water addition could maximize the soil water content (Liang et al., 2014), as also found in our current study (Fig. 4a). Besides the physical properties, the chemical restoration of soil is clearly important for soil quality improvement (Lal, 2015). In our study, the availability of $\mathrm{N}$ significantly enhanced with the increase of $\mathrm{W}$ and $\mathrm{CMC}$, regardless of BC additions (Fig. 4b). The reason behind this fact is that high soil water content enhance $\mathrm{N}$ mineralization of $\mathrm{CMC}$, however, most of the $\mathrm{N}$ would be burns off and become non-bioavailable in biochar due to being pyrolyzed at $400{ }^{\circ} \mathrm{C}$ temperature (Marshall et al., 2019). However, availability of P and K significantly increased with the high W, CMC and BC applications, which is key to restore the quality of alkaline-soil (Zhang et al., 2020). Biochar can also improve the efficiency of inorganic and organic fertilizers by enhancing microbial functions and reducing nutrient loss, thereby making nutrients more available to plants. As biochar can adsorb nutrients and provide microbial habitat, it can also retain fertilizers in soil longer than control soil and prevent leaching losses of nutrients. However, pathogen inactivation is expected to occur in compost, since the temperature during composting has to be maintained over $55{ }^{\circ} \mathrm{C}$ for at least 3 days. Enhancing physical-chemical properties of soil have a beneficial effect on biological soil quality restoration (Li et al., 2002). The use of CMC and BC significantly increased urease and catalase activities (Fig. 4e and f), which may be attributed to their high nutrient and carbon content, also bearing in mind that their adequate aeration and surface area provided an excellent environment for the growth of microbes (Verheijen et al., 2019). The created favorable conditions due to $\mathrm{CMC}$ and $\mathrm{BC}$ applications helps to improve the growth and reproduction of soil microorganisms and thereby promote soil enzymatic activities (Gul et al., 2015; Nie et al., 2018). However, W-shortage conditions caused the death of some soil microorganisms, which drastically reduce the urease and catalase activity (Sardans and Peñuelas, 2005). Despite the fact that water scarcity raised ROS, the CMC-BC application improves water and nutrient availability, increasing leaf water status, osmolytes, and antioxidant enzyme activities, and assisting $O$. viciifolia in amplifying photosynthetic pigment contents and, ultimately, plant growth parameters (Figs. 2 and 3; Table 2). Moreover, soil water and nutrients contents, and enzyme activities also remarkably increased with the additions of CMC and BC (Fig. 4a-f). The analysis results of Pearson's correlation coefficient and heatmap approach further supported these findings (Fig. 5a and b).

Overall, taking into account that the major objective of the current study is to assess the conditions to promote revegetation with $O$. viciifolia and subsequent restoration in a mined degraded arid region of Northwestern China, by supplying optimum W (64\% FC), CMC (2.4\%) and BC (1.7\%) application rates, as offered by RSM (Fig. 5c), which could optimize $O$. viciifolia growth on coal-mined spoils and also improves soil biological, chemical, and physical properties. Thus, the combined use of optimal W-CMC-BC doses together with $O$. viciifolia could be utilized for vegetation and ecological restoration in coal mine areas of Northwestern China, and across other semi-arid areas worldwide.

\section{Conclusion}

Our study showed that application of W-CMC-BC doses positively influenced different growth attributes of $O$. viciifolia. The detrimental effect of W-shortage was reduced with CMC and BC application, resulting in an improvement of plant morpho-physiological status, indicated by higher morphological growth attributes, osmolytes content and antioxidant enzyme activity, and lower oxidative damage. The addition of CMC-BC resources caused soil physical-chemical properties and enzyme activities to be clearly more enhanced under high-W than low-W regimes. The $O$. viciifolia supplied with appropriate W-CMC-BC doses $\left(\mathrm{W}_{64} \mathrm{CMC}_{2.4} \mathrm{BC}_{1.7}\right)$, may be very resistant to environmental stresses and capable of growing in coal-mined degraded arid environments worldwide.

\section{Credit author statement}

Rana Roy: Conceptualization, Data curation, Formal analysis, Investigation, Methodology, Made graphs and figures, Software, Supervision, Visualization, Writing-original draft, Writing - review \& editing. Avelino Núñez-Delgado: Writing - review \& editing. Jinxin Wang: Resources, Project administration, Funding acquisition. Md. Abdul Kader: Writing - review \& editing. Tanwne Sarker: Investigation, Visualization. Ahmed Khairul Hasan: Made graphs and figures. Turgay Dindaroglu: Made graphs and figures.

\section{Declaration of competing interest}

The authors declare that they have no known competing financial interests or personal relationships that could have appeared to influence the work reported in this paper.

\section{Acknowledgements}

This work was supported by Research and Innovation Team of Key Technologies for Ecological Protection and Restoration, Quality Improvement and Efficiency Enhancement of the Yellow River Basin of Shaanxi Academy of Forestry Sciences (SXLK 2020-0305); National Key Research and Development Program of China (2017YFC0504402); National Natural Science Foundation of China (31670713).

\section{Appendix A. Supplementary data}

Supplementary data to this article can be found online at https://doi. org/10.1016/j.envres.2021.112440.

\section{References}

Abideen, Z., Koyro, H.W., Huchzermeyer, B., Gul, B., Khan, M.A., 2020. Impact of a biochar or a biochar-compost mixture on water relation, nutrient uptake and photosynthesis of Phragmites karka. Pedosphere 30, 466-477. https://doi.org/ 10.1016/S1002-0160(17)60362-X.

Aydin, Adil, 2012. Humic acid application alleviate salinity stress of bean (Phaseolus vulgaris L.) plants decreasing membrane leakage. AFRICAN J. Agric. RESEEARCH 7, 1073-1086. https://doi.org/10.5897/ajar10.274.

Al-Wabel, M.I., Al-Omran, A., El-Naggar, A.H., Nadeem, M., Usman, A.R.A., 2013. Pyrolysis temperature induced changes in characteristics and chemical composition of biochar produced from conocarpus wastes. Bioresour. Technol. 131, 374-379. https://doi.org/10.1016/j.biortech.2012.12.165.

Antonious, G.F., 2018. Biochar and animal manure impact on soil, crop yield and quality. In: Agricultural Waste and Residues, pp. 45-67. https://doi.org/10.5772/ intechopen.77008.

Bates, L.S., Waldren, R.P., Teare, I.D., 1973. Rapid determination of free proline for water-stress studies. Plant Soil 39, 205-207. https://doi.org/10.1007/BF00018060.

Beesley, L., Moreno-Jiménez, E., Gomez-Eyles, J.L., Harris, E., Robinson, B., Sizmur, T., 2011. A review of biochars' potential role in the remediation, revegetation and restoration of contaminated soils. Environ. Pollut. 159, 3269-3282. https://doi.org/ 10.1016/j.envpol.2011.07.023.

Bianco, F., Race, M., Papirio, S., Oleszczuk, P., Esposito, G., 2021. The addition of biochar as a sustainable strategy for the remediation of PAH-contaminated 
sediments. Chemosphere 263, 128274. https://doi.org/10.1016/j. chemosphere.2020.128274.

Cechin, I., Rossi, S.C., Oliveira, V.C., Fumis, T.F., 2006. Photosynthetic responses and proline content of mature and young leaves of sunflower plants under water deficit. Photosynthetica 44, 143-146. https://doi.org/10.1007/s11099-005-0171-2.

Claoston, N., Samsuri, A.W., Ahmad Husni, M.H., Mohd Amran, M.S., 2014. Effects of pyrolysis temperature on the physicochemical properties of empty fruit bunch and rice husk biochars. Waste Manag. Res. 32, 331-339. https://doi.org/10.1177/ $0734242 \times 14525822$.

Cybulak, M., Sokołowska, Z., Boguta, P., 2016. Hygroscopic moisture content OF podzolic soil with biochar. Acta Agroph 23, 533-543.

Das, K., Roychoudhury, A., 2014. Reactive oxygen species (ROS) and response of antioxidants as ROS-scavengers during environmental stress in plants. Front. Environ. Sci. 2, 1-13. https://doi.org/10.3389/fenvs.2014.00053.

Dimkpa, C.O., Andrews, J., Sanabria, J., Bindraban, P.S., Singh, U., Elmer, W.H., GardeaTorresdey, J.L., White, J.C., 2020. Interactive effects of drought, organic fertilizer, and zinc oxide nanoscale and bulk particles on wheat performance and grain nutrient accumulation. Sci. Total Environ. 722, 137808. https://doi.org/10.1016/j. scitotenv.2020.137808.

Gao, X., Zhao, X., Wu, P., Brocca, L., Zhang, B., 2016. Effects of large gullies on catchment-scale soil moisture spatial behaviors: a case study on the Loess Plateau of China. Geoderma 261, 1-10. https://doi.org/10.1016/j.geoderma.2015.07.001.

Gomes Silveira, J.A., De Almeida Viégas, R., Almeida Da Rocha, I.M., De Oliveira Monteiro Moreira, A.C., De Azevedo Moreira, R.D., Abreu Oliveira, J.T., 2003 Proline accumulation and glutamine synthetase activity are increased by saltinduced proteolysis in cashew leaves. J. Plant Physiol. 160, 115-123. https://doi. org/10.1078/0176-1617-00890.

Guan, Y., 1986. Soil Enzymes and Their Research Methods. China Agric. Press.

Gul, S., Whalen, J.K., Thomas, B.W., Sachdeva, V., Deng, H., 2015. Physico-chemical properties and microbial responses in biochar-amended soils: mechanisms and future directions. Agric. Ecosyst. Environ. 206, 46-59. https://doi.org/10.1016/j agee.2015.03.015.

Gururani, M.A., Upadhyaya, C.P., Baskar, V., Venkatesh, J., Nookaraju, A., Park, S.W., 2013. Plant growth-promoting rhizobacteria enhance abiotic stress tolerance in Solanum tuberosum through inducing changes in the expression of ROS-scavenging enzymes and improved photosynthetic performance. J. Plant Growth Regul. 32, 245-258. https://doi.org/10.1007/s00344-012-9292-6.

Hopkins, D.W., Alef, K., Nannipieri, P., 1996. Methods in applied soil microbiology and biochemistry. J. Appl. Ecol. https://doi.org/10.2307/2405027.

Joseph, B.Y., 1955. In blood and reagent*. J. Biol. Chem. 212, 335-343.

Joseph, S.D., Camps-Arbestain, M., Lin, Y., Munroe, P., Chia, C.H., Hook, J., Van Zwieten, L., Kimber, S., Cowie, A., Singh, B.P., Lehmann, J., Foidl, N., Smernik, R.J., Amonette, J.E., 2010. An investigation into the reactions of biochar in soil. Aust. J. Soil Res. 48, 501-515. https://doi.org/10.1071/SR10009.

Ke, D. Sen, Wang, A.G., Sun, G.C., Dong, L.F., 2002. The effect of active oxygen on the activity of ACC synthase induced by exogenous IAA. Acta Bot. Sin. 44, 551-556.

Keiluweit, M., Nico, P.S., Johnson, M., Kleber, M., 2010. Dynamic molecular structure of plant biomass-derived black carbon (biochar). Environ. Sci. Technol. 44, 1247-1253. https://doi.org/10.1021/es9031419.

Kheirizadeh Arough, Y., Seyed Sharifi, Raouf, Seyed Sharifi, Reza, 2016. Bio fertilizers and zinc effects on some physiological parameters of triticale under water-limitation condition. J. Plant Interact. 11, 167-177. https://doi.org/10.1080/ 17429145.2016 .1262914$.

Kong, J., Pei, Z., Du, M., Sun, G., Zhang, X., 2014. Effects of arbuscular mycorrhizal fung on the drought resistance of the mining area repair plant Sainfoin. Int. J. Min. Sci. Technol. 24, 485-489. https://doi.org/10.1016/j.ijmst.2014.05.011.

Kumar, A., Sharma, K.D., 2010. Leaf water content-a simple indicator of drought tolerance in crop plants. Indian J. Agric. Sci. 80, 1095-1097.

Lal, R., 2015. Restoring soil quality to mitigate soil degradation. Sustain. Times 7 , 5875-5895. https://doi.org/10.3390/su7055875.

Li, C.H., Ma, B.L., Zhang, T.Q., 2002. Soil bulk density effects on soil microbial populations and enzyme activities during the growth of maize (Zea mays L.) planted in large pots under field exposure. Can. J. Soil Sci. 82, 147-154. https://doi.org/ 10.4141/S01-026.

Li, Y., Cao, Z., Long, H., Liu, Y., Li, W., 2017. Dynamic analysis of ecological environment combined with land cover and NDVI changes and implications for sustainable urban-rural development: the case of Mu Us Sandy Land, China. J. Clean. Prod. 142, 697-715. https://doi.org/10.1016/j.jclepro.2016.09.011.

Liang, C., Gascó, G., Fu, S., Méndez, A., Paz-Ferreiro, J., 2016. Biochar from pruning residues as a soil amendment: effects of pyrolysis temperature and particle size. Soil Tillage Res. 164, 3-10. https://doi.org/10.1016/j.still.2015.10.002.

Liang, X., Gao, Y., Zhang, X., Tian, Y., Zhang, Z., Gao, L., 2014. Effect of optimal daily fertigation on migration of water and salt in soil, root growth and fruit yield of cucumber (Cucumis sativus L.) in solar-greenhouse. PLoS One 9, e86975. https:// doi.org/10.1371/journal.pone.0086975.

Lu, R., 2000. Analytical Methods of Soil Agro-Chemistry. Chinese Agric. Press, Beijing.

Luo, Y., Dungait, J.A.J., Zhao, X., Brookes, P.C., Durenkamp, M., Li, G., Lin, Q., 2018. Pyrolysis temperature during biochar production alters its subsequent utilization by microorganisms in an acid arable soil. Land Degrad. Dev. 29, 2183-2188. https:// doi.org/10.1002/ldr.2846.

Marshall, J., Muhlack, R., Morton, B.J., Dunnigan, L., Chittleborough, D., Kwong, C.W., 2019. Pyrolysis temperature effects on biochar-water interactions and application for improved water holding capacity in vineyard soils. Soil Syst 3, 27. https://doi. org/10.3390/soilsystems3020027.

Nie, C., Yang, X., Niazi, N.K., Xu, X., Wen, Y., Rinklebe, J., Ok, Y.S., Xu, S., Wang, H., 2018. Impact of sugarcane bagasse-derived biochar on heavy metal availability and microbial activity: a field study. Chemosphere 200, 274-282. https://doi.org/ 10.1016/j.chemosphere.2018.02.134.

Nigussie, A., Kissi, E., Misganaw, M., Ambaw, G., 2012. Effect of biochar application on soil properties and nutrient uptake of lettuces (Lactuca sativa) grown in chromium polluted soils. Environ. Sci. 12, 369-376.

Niu, S., Li, S., 2003. Research on the effects of sainfoin planting on soil fertility. Gansu Agric Sci Technol 3, 40-41.

Ogbaga, C.C., Stepien, P., Johnson, G.N., 2014. Sorghum (Sorghum bicolor) varieties adopt strongly contrasting strategies in response to drought. Physiol. Plantarum 152, 389-401. https://doi.org/10.1111/ppl.12196.

Pandey, B., Singh, S., Roy, L.B., Shekhar, S., Singh, R.K., Prasad, B., Singh, K.K.K., 2021. Phytostabilization of coal mine overburden waste, exploiting the phytoremedial efficacy of lemongrass under varying level of cow dung manure. Ecotoxicol. Environ. Saf. 208, 111757. https://doi.org/10.1016/j.ecoenv.2020.111757.

Pradhan, S., Abdelaal, A.H., Mroue, K., Al-Ansari, T., Mackey, H.R., McKay, G., 2020 Biochar from vegetable wastes: agro-environmental characterization. Biochar 2 439-453. https://doi.org/10.1007/s42773-020-00069-9.

Rahman, M.A., Jahiruddin, M., Kader, M.A., Islam, M.R., Solaiman, Z.M., 2021 Sugarcane bagasse biochar increases soil carbon sequestration and yields of maize and groundnut in charland ecosystem. Arch. Agron Soil Sci. 1-14. https://doi.org/ 10.1080/03650340.2021.1892651.

Rao, D.M.R., Kodandaramaiah, J., Reddy, M.P., Katiyar, R.S., Rahmathulla, V.K., 2007. Effect of VAM fungi and bacterial biofertilizers on mulberry leaf quality and silkworm cocoon characters under semiarid conditions. Casp. J. Environ. Sci. Casp. J. Env. Sci 5, 111-117.

Ren, T., Chen, N., Wan Mahari, W.A., Xu, C., Feng, H., Ji, X., Yin, Q., Chen, P., Zhu, S., Liu, H., Liu, G., Li, L., Lam, S.S., 2021. Biochar for cadmium pollution mitigation and stress resistance in tobacco growth. Environ. Res. 192, 110273. https://doi.org/ 10.1016/j.envres.2020.110273.

Roy, R., Mostofa, M.G., Wang, J., Fornara, D., Sarker, T., Zhang, R., 2021a. Revegetation intervention of drought-prone coal-mined spoils using Caragana korshinskii under variable water and nitrogen-phosphorus resources. Agric. Water Manag. 246, 106712. https://doi.org/10.1016/j.agwat.2020.106712.

Roy, R., Mostofa, M.G., Wang, J., Sikdar, A., Sarker, T., 2020a. Improvement of growth performance of Amorpha fruticosa under contrasting regime of water and fertilizer in coal-contaminated spoils using response surface methodology. BMC Plant Biol. 20, 1-15. https://doi.org/10.1186/s12870-020-02397-1.

Roy, R., Nú nez-Delgado, A., Sultana, S., Wang, J., Munir, A., Battaglia, M.L., Sarker, T., Seleiman, M.F., Barmon, M., Zhang, R., 2021b. Additions of optimum water , spent mushroom compost and wood biochar to improve the growth performance of Althaea rosea in drought-prone coal-mined spoils. J. Environ. Manag. 295, 113076. https://doi.org/10.1016/j.jenvman.2021.113076.

Roy, R., Sultana, S., Begum, N., Fornara, D., Barmon, M., Zhang, R., Sarker, T., Roy, R., 2021c. Exogenous melatonin reduces water deficit-induced oxidative stress and improves growth performance of Althaea rosea grown on coal mine spoils. Environ. Sci. Pollut. Res. https://doi.org/https://doi.org/10.1007/s11356-021-14671-2.

Roy, R., Sultana, S., Wang, J., Golam, M., Sarker, T., Rahman, M.M., Shakhawat, M., 2022. Revegetation of coal mine degraded arid areas : the role of a native woody species under optimum water and nutrient resources. Environ. Res. 204, 111921. https://doi.org/10.1016/j.envres.2021.111921.

Roy, R., Wang, J., Golam, M., Fornara, D., Sikdar, A., Sarker, T., Wang, X., Shah, M. 2020b. Fine-tuning of soil water and nutrient fertilizer levels for the ecological restoration of coal-mined spoils using Elaeagnus angustifolia. J. Environ. Manag. 270, 110855. https://doi.org/10.1016/j.jenvman.2020.110855.

Roy, R., Wang, J., Mostofa, M.G., Fornara, D., 2021d. Optimal water and fertilizer applications improve growth of Tamarix chinensis in a coal mine degraded area under arid conditions. Physiol. Plantarum 172, 371-390. https://doi.org/10.1111/ ppl.13147.

SAA, 1977. Standards Association of Australia (SAA). AS 1289E 3.3.Determination of the Field Dry Density of a Soil: Core Cutter Method for Fine-Grained Soils.

Salehi, A., Tasdighi, H., Gholamhoseini, M., 2016. Evaluation of proline, chlorophyll, soluble sugar content and uptake of nutrients in the German chamomile (Matricaria chamomilla L.) under drought stress and organic fertilizer treatments. Asian Pac. J. Trop. Biomed. 6, 886-891. https://doi.org/10.1016/j.apjtb.2016.08.009.

Sardans, J., Peñuelas, J., 2005. Drought decreases soil enzyme activity in a Mediterranean Quercus ilex L. forest. Soil Biol. Biochem. 37, 455-461. https://doi. org/10.1016/j.soilbio.2004.08.004.

Sun, Y.Z., Fan, J.S., Qin, P., Niu, H.Y., 2009. Pollution extents of organic substances from a coal gangue dump of Jiulong Coal Mine, China. Environ. Geochem. Health 31, 81-89. https://doi.org/10.1007/s10653-008-9158-9.

Tag, A.T., Duman, G., Ucar, S., Yanik, J., 2016. Effects of feedstock type and pyrolysis temperature on potential applications of biochar. J. Anal. Appl. Pyrolysis 120 , 200-206. https://doi.org/10.1016/j.jaap.2016.05.006.

Velikova, V., Yordanov, I., Edreva, A., 2000. Oxidative stress and some antioxidant systems in acid rain-treated bean plants. Plant Sci. 151, 59-66. https://doi.org/ 10.1016/s0168-9452(99)00197-1.

Verheijen, F.G.A., Zhuravel, A., Silva, F.C., Amaro, A., Ben-Hur, M., Keizer, J.J., 2019 The influence of biochar particle size and concentration on bulk density and maximum water holding capacity of sandy vs sandy loam soil in a column experiment. Geoderma 347, 194-202. https://doi.org/10.1016/j. geoderma.2019.03.044

Wang, K., Yin, X., Mao, H., Chu, C., Tian, Y., 2018. Changes in structure and function of fungal community in cow manure composting. Bioresour. Technol. 255, 123-130. https://doi.org/10.1016/j.biortech.2018.01.064. 
Wong, M.H., 2003. Ecological restoration of mine degraded soils, with emphasis on metal contaminated soils. Chemosphere 50, 775-780. https://doi.org/10.1016/S00456535(02)00232-1.

Xie, L., van Zyl, D., 2020. Distinguishing reclamation, revegetation and phytoremediation, and the importance of geochemical processes in the reclamation of sulfidic mine tailings: a review. Chemosphere 252, 126446-1266457. https://doi. org/10.1016/j.chemosphere.2020.126446.

Xie, Y., Dong, C., Chen, Z., Liu, Y., Zhang, Y., Gou, P., Zhao, X., Ma, D., Kang, G., Wang, C., Zhu, Y., Guo, T., 2021. Successive biochar amendment affected crop yield by regulating soil nitrogen functional microbes in wheat-maize rotation farmland. Environ. Res. 194, 110671. https://doi.org/10.1016/j.envres.2020.110671.

Xu, X., Zhang, D., Zhang, Y., Yao, S., Zhang, J., 2020. Evaluating the vegetation restoration potential achievement of ecological projects: a case study of Yan'an, China. Land Use Pol. 90, 104293-104302. https://doi.org/10.1016/j. landusepol.2019.104293.
Yu, J., Liu, F., Tripathi, B.M., Steinberger, Y., 2020. Changes in the composition of soil bacterial and fungal communities after revegetation with Caragana microphylla in a desertified semiarid grassland. J. Arid Environ. 182 https://doi.org/10.1016/j. jaridenv.2020.104262.

Yuan, J.H., Xu, R.K., Zhang, H., 2011. The forms of alkalis in the biochar produced from crop residues at different temperatures. Bioresour. Technol. 102, 3488-3497. https://doi.org/10.1016/j.biortech.2010.11.018.

Zhang, X., Qu, J., Li, H., La, S., Tian, Y., Gao, L., 2020. Biochar addition combined with daily fertigation improves overall soil quality and enhances water-fertilizer productivity of cucumber in alkaline soils of a semi-arid region. Geoderma 363 , 114170. https://doi.org/10.1016/j.geoderma.2019.114170.

Zinati, G.M., Li, Y.C., Bryan, H.H., 2001. Utilization of compost increases organic carbon and its humin, humic and fulvic fraction in calcareous soil. Compost Sci. Util. 9, 156-162. https://doi.org/10.1080/1065657X.2001.10702030. 